\title{
METAMORFÓZY KOŠICKEJ ČINOHERNEJ DRAMATURGIE (1924 - 1970)
}

\author{
PETER HIMIČ
}

Fakulta dramatických umení, Akadémia umení v Banskej Bystrici

\begin{abstract}
Abstrakt: Štúdia načrtáva obrysy vývoja činohernej dramaturgie v slovenskom profesionálnom divadle v Košiciach, od vzniku Východoslovenského národného divadla v roku 1924 po začiatok tzv. normalizácie. Pomenováva základné dramaturgické okruhy a vývojové tendencie. V dejinách košickej profesionálnej činohry sa ukazuje niekol'ko problémových etáp. V menšej miere sa vyskytovali kompaktné dramaturgické obdobia, no len občas prerástli do dlhodobejšieho umeleckého programu. Jedným zo závažných dôvodov tohto stavu bola absencia intenzívnejšej a ideovo-esteticky opodstatnenej dramaturgickej vízie vo vztahu k hereckému súboru a režisérskej práci. Navyše, tento vztłah často komplikovala dominantnost’ režisérov, niekedy nad ich umelecké možnosti. Klúčovú úlohu zohrával aj stret staršej a nastupujúcej mladej generácie, ovplyvnenej povojnovou modernou drámou a divadlom.

Klúčové slová: činoherná dramaturgia, dramaturg, režisér, Košice, Východoslovenské národné divadlo, Národné divadlo v Košiciach, Štátne divadlo Košice, pôvodná dráma
\end{abstract}

Z doterajších výstupov a na základe výskumu sa pre pomenovanie špecifík a vnútorných tendencií genézy košickej činohry ukazuje byt podstatným vztah medzi dramaturgiou a réžiou. V Košiciach viac než inde boli dramaturgické predstavy podrobené skúške zo strany režisérov a ich inscenačných výsledkov. Tieto vnútorne zložité a osobnostne załažené korelácie boli nielen príčinou vzájomného napätia, ale vo výsledku hatili rozvoj celého súboru, s najväčším dopadom na hereckú čast'. Aby bolo možné pregnantnejšie a hlbšie vypovedat o vývoji košickej činohry, je potrebné analyzovat dramaturgické línie, ktoré v mnohom predurčovali jej budúci charakter.

Aj ked' dnešné Štátne divadlo začalo svoju činnosṫ až po druhej svetovej vojne, pre komplexný pohlad na slovenské profesionálne divadlo $\mathrm{v}$ meste je dobré sledovat aj medzivojnové obdobie, teda činnost Východoslovenského národného divadla od jeho vzniku v roku 1924. To umožní komplexnejšie zmapovat ideovo-estetické tendencie a etapy, ktoré vnútorne vykazujú ucelenú podobu. $V$ istých obdobiach ide o silné prepojenie repertoárovej politiky na režisérske osobnosti, ktoré podstatným spôsobom formulovali dramaturgické preferencie. Ani existencia pozície interného dramaturga po roku 1945 neznamenala chápanie jeho práce ako súboru dlhodobých a vnútorne podmienených činností s textom, nad textom a pre text, s režisérom a preňho, a v neposlednom rade pre herecký súbor.

Doterajší výskum dejín košickej dramaturgie (na pozadí vztahu dramaturg - režisér) generuje jej tri typy, ktoré zároveň ponúkajú metodologické možnosti nazerania na metamorfózy činohry: (1) dependentnú, ako výsledok dominantného postavenia režiséra, (2) independentnú, bez väzby na umelecký materiál súboru, (3) autonómnu, ako výsledok premyslenej a umelecky opodstatnenej kooperácie medzi reprezentantmi všetkých zložiek budúcej inscenačnej štruktúry. Túto typológiu je potrebné vnímat ako rámce, ktoré generovali tematické (dramaturgia) a poetologické (réžia) okruhy. Preskupovanie v rámci nich bolo prirodzené, determinované aj mimoumeleckými skutočnostami. 


\section{$1924-1938$}

V roku 1924 vznikla v Košiciach po Slovenskom národnom divadle (SND) druhá česko-slovenská divadelná profesionálna scéna na Slovensku, Východoslovenské národné divadlo (VND). ${ }^{1}$ Existovalo do roku 1930, malo činoherný a spevoherný súbor, obidva boli pod vplyvom umeleckých a finančných preferencií riaditel'ov (Josef Hurt, 1924 - 1926; Oto Alferi, 1926 - 1928; Otakar Novák, 1928 - 1929; Karel a Drahoš Želenskí, 1929 - 1930).

VND bolo od začiatku českým divadlom. Hrávalo po česky, s výnimkou pôvodnej slovenskej tvorby a niekol'kých inojazyčných hier preložených do slovenčiny.

Prvé vedenie divadla (režisér Hurt ako riaditel' a herec Ján Sýkora ako umelecký šéf) sa to snažilo hned' od začiatku kompenzovat' zarad'ovaním slovenských hier do repertoáru. Po vyše štyroch rokoch od českých otváracích inscenácií SND začínala česká činohra VND slovenskou hrou Jána Chalupku Kocúrkovo. Podla divadelného historika Milana Poláka, „Uvedenie Chalupkovej veselohry akoby chcelo predznamenat', že divadlo si bude plnit' povinnost’ aj voči uvádzaniu hier v slovenskom jazyku, a to aj napriek tomu, že takmer celý ansámbel tvorili českí herci."2 Režisér inscenácie Ján Sýkora mal k dispozícii úpravu Jaroslava Hanku, ktorá posilňovala štýlovo odlišné druhé dejstvo originálu (tzv. lesnú scénu) v jeho romantizujúcom až operetnom duchu. Vložil hudobné a baletné čísla a otupil spoločenskú kritickost̉ diela. Bolo to prvé uvedenie Jána Chalupku na našej profesionálnej scéne. Slovenskými profesionálnymi premiérami v prvej sezóne boli aj Tma a Smrt’ Ďurka Langsfelda Jozefa Gregora Tajovského, Osudná zámena Rehora Urama-Podtatranského, Večná mladost' Kvetoslava Floriána Urbanoviča a Krpčeky svätého Floriána Ladislava Nádáši-Jégého. Hurtova dramaturgia tak zvýrazňovala výčitky bratislavskej kritiky, reflektujúce nedostatok slovenských hier v repertoári činohry SND. Košická činohra mala od začiatku ambíciu „predviest' hodnotné hry slovenské, pokial' ešte neboly hrané, a klasické hry české ako aj najlepšie hry cudzie, aby tak bola zachovaná jednotná línia“3. Pre Urbanoviča sa košická scéna stala v podstate domovskou, v roku 1926 tu uviedli aj jeho hry Zlatý močiar a Poklesky.

Mnohé hry, ktoré naštudovalo VND, je možné zaznamenat' aj v počiatkoch SND, čo pri svetovej dramatickej literatúre v tom čase často súviselo s nedostatkom prekladov. V prvej košickej sezóne režíroval Hurt i zásadné diela svetovej drámy (Molière: Lekárom proti svojej wôli, Sganarelle, Frank Wedekind: Lulu, William Shakespeare: Král' Lear), ale českí autori mali pochopitel’ne prevahu. K profilovým košickým Hurtovým réžiám patrí inscenácia hry Karla Čapka R. U. R. (1926).

Režisér Jan Škoda režíroval väčšinou umelecky nehodnotné veselohry a frašky. Za zmienku však stojí jeho inscenácia hry Imreho Madácha Tragédia človeka (1925)

\footnotetext{
${ }^{1}$ K podrobnejšej analýze vzniku, existencii a umeleckej úrovni VND pozri HIMIČ, P. Divadlo na východnom Slovensku I. : Od počiatkov do roku 1945. Banská Bystrica : Fakulta dramatických umení, Akadémia umení v Banskej Bystrici, 2020, s. $70-85$.

2 POLAK, M. Premiéry Východoslovenského národného divadla v Košiciach 1924 - 1930 a 1937 - 1938. Bratislava : NDC, 1995, s. 17.

${ }^{3}$ lk. Divadlo na východnom Slovensku a Podkarpatskej Rusi. In Za oponou, 1924, roč. 1, č. 4, s. 3. Za oponou bol časopis, ktorý vydávalo VND. Pri citáciách z dobových článkov zachováme vtedajšiu formu pravopisu.
} 
v preklade Pavla Országha Hviezdoslava. ${ }^{4}$ Režisér spolu s Hurtom túto náročnú predlohu dramaturgicky upravili, ale nezoškrtali: „V našom prevedení nesiahla réžia k tomuto prostriedku a volila previest̉ radšie dielo celé, neochudzovat ho práve o tie najkrajšie partie básne a previedla redukciu textu $\mathrm{v}$ podradnejších scénach. Úloha to bola dvojnásobne obtažná, lebo slovenský preklad nevyniká stručnostou a dramatičnostou reči, ako na príklad český preklad Brábkov. ${ }^{\prime 5} \mathrm{~V}$ pôvodnom jazyku sa Madáchova dráma na košickom javisku už hrala, ale v slovenčine zaznela u nás po prvýkrát. Počas siedmich rokov všetky vedenia pravidelne zarad’ovali do repertoáru hry mad’arských autorov.

Aj po odchode Hurta sa dramaturgia divadla snažila zachovat’ žánrovú a tematickú rôznorodost’ premierovaných pôvodných hier. Hry košického autora, učitela, literárneho a rozhlasového redaktora, divadelného recenzenta Emila Ruska Plamene (1928) a Červená opica (1929, spolu s Arpádom Juhászom) radí divadelný historik Vladimír Štefko k tým, ktoré nadväzovali na modernistickú líniu v košickej dramaturgii, rovnako aj hru Márie Oravcovej Prielom do večnosti (1929): „Nie je bez zaujímavosti, že košické Východoslovenské národné divadlo prejavilo pre tento typ pôvodnej dramatiky väčší zmysel než Slovenské národné divadlo v Bratislave." 6 Táto ústretovost' vyplývala aj z mimoumeleckých dôvodov. Na rozdiel od bratislavskej kritiky bola miestna tlač k experimentálnym hrám zhovievavejšia, vítala najmä fakt, že ide o košických autorov. Ich uvádzaním sa riaditel' Alferi zároveň snažil dodržat’ podmienky, za ktorých mu družstvo udelilo koncesiu, t. j. zostavovat dramaturgiu s ohl'adom na pôvodnú slovenskú dramatickú tvorbu. Túto povinnost̉ prevzali aj d’alší riaditelia. Vedenie divadla dokonca vypísalo sútaž na pôvodnú celovečernú hru (takto sa na košickú scénu dostala Krútřava Emila Ruska a Júliusa Štefančíka, 1930). Napriek tomu sa ich s pribúdajúcimi rokmi neuvádzalo tol'ko ako predtým, pričom išlo o kvantitatívne naplnenie. Ako konštatoval divadelný historik Zoltán Rampák, „nejaká dramaturgická línia v košických slovenských predstaveniach nejestvovala, výber hier bol vel'mi náhodný ${ }^{\prime 7}$ a väčšinou prebratý z bratislavskej dramaturgie.

Alferi režíroval menej, zato si viac vyberal: uviedol Shakespearovho Othella (1927), Wedekindovo Jarné prebudenie (1927), Slečnu Júliu (1928) Augusta Strindberga. V jeho riaditel'skom období sa repertoár tvoril často narýchlo a náhodne. Nepovšimnutou v dejinách košického divadla je dramaturgia režírujúceho herca Václava Kosteleckého, ktorý pôsobil v Novákovej ére. V malom počte jeho réžií zaujmú najmä Morálka pani Dulskej Gabriely Zapolskej (1928), Krečinskij sa žení Alexandra Suchovo-Kobylina (1929) a Hra o láske a smrti Romaina Rollanda (1929). Aj d’alšiemu režírujúcemu hercovi, Ludvíkovi Řezníčkovi, bola prekvapujúco pridelená kvalitná dramaturgia, napríklad Ideálny manžel Oscara Wilda, Radúz a Mahuliena Juliusa Zeyera, Vláda tmy Leva Nikolajeviča Tolstého (všetky 1928).

Dramaturgie Karla a Drahoša Želenských boli značne nevyvážené. Väčšie režisérske ambície prejavil Drahoš (Shakespeare: Romeo a Júlia, 1929; Nikolaj Vasilievič

\footnotetext{
${ }^{4}$ V súpise premiér VND Milan Polák chybne uvádza Hurta ako režiséra inscenácie. POLÁK, M. Premiéry Východoslovenského národného divadla v Košiciach 1924 - 1930 a 1937 - 1938. Bratislava : NDC, 1995, s. 35.

${ }^{5}$ Jša. [Jan Škoda] Čin. K premiére „Tragédie človeka“. In Za oponou, 1925, roč. 2, č. 16, s. 13.

6 ŠTEFKO, V. Od realizmu k moderne 1890 - 1938. In ŠTEFKO, V. a kol. Dejiny slovenskej drámy 20. storočia. Bratislava : Divadelný ústav, 2011, s. 40.

${ }^{7}$ RAMPÁK, Z. Z minulosti VND v Košiciach : 1920 - 1938. In Národné divadlo v Košiciach : Jubilejné číslo programu ND v Košiciach. (Zredigoval J. Zborovjan.) Košice : ND v Košiciach, 1955, s. 22.
} 
Gogol: Revízor, 1930; George Bernard Shaw: Pygmalion,1930). Jánovi Sýkorovi, ktorý pôsobil v košickom divadle najdlhšie (1924 - 1929), ostala povinnost’ vyvažovat’ dramaturgiu riaditel’ov realistickým repertoárom. Ako umelecký šéf zobral na seba aj riziko uvádzania noviniek miestnych autorov. K jeho významnejším inscenáciám, popri Kocúrkove, patrila Nora Henrika Ibsena (1928).

VND bolo doslova zahltené novými titulmi, za sedem rokov činnosti uvádzalo ročne v priemere 30 premiér (mimo spevohry). Aj preto Jan Škoda charakterizoval repertoár ako „väčšinou eklektický“, ked’že divadlo sa muselo „,často zapret', čo vyžadovalo jeho povolanie buditel'ské“", pričom v prvom rade „bol to zretel' k slovenskej literatúre dramatickej“. ${ }^{8} \mathrm{~V}$ Hurtovom období, ked’ malo družstvo priamy vplyv na riadenie divadla, existovala pri ňom aj dramaturgická komisia zložená z členov z externého kultúrno-spoločenského prostredia. Tá však zasahovala len do mesačného hracieho plánu, nie do dramaturgie.

Divadlo počas celej svojej existencie narážalo na malý záujem zo strany obecenstva. Najmä vážny repertoár spôsoboval finančné problémy. Konkurenciou mu boli oblúbené predstavenia spevoherného súboru a hostovania SND. Košice navštevovali aj rôzne súkromné divadelné spoločnosti s l’ahším repertoárom a estrádnymi vystúpeniami populárnych hercov a spevákov z Prahy a Bratislavy. Po Hurtovom odchode dramaturgia preferovala l'ahší veseloherný a spevoherný žáner. Ani to však nestačilo. Záujem publika ochaboval, štátna a miestna podpora bola z roka na rok menšia a neistá. Zadlžený riaditel' Novák spáchal samovraždu a o necelý rok ohlásil Drahoš Želenský zánik divadla, čo sa ku koncu sezóny 1929/1930 skutočne stalo.

V roku 1937 VND obnovilo svoju činnost', no nie ako samostatná inštitúcia, ale ako filiálka SND. Jeho riaditel' Antonín Drašar prejavoval pochopenie pre uvádzanie slovenských hier, resp. inscenácií v slovenskej reči. Za riaditela vymenoval speváka Fraňa Devinského, ktorý sa prioritne venoval administratívnym záležitostiam. Dramaturgiu formoval hlavný režisér divadla Jaroslav Skála (popri ňom režíroval české hry aj Ota Ornest a hry v slovenčine Ivan Lichard), ktorý však nenadviazal na snahy spred desiatich rokov. Z 24 premiér v sezóne iba v siedmich zaznela z košického javiska slovenčina. Z pôvodných to boli Stodolovi Vel’komožní páni, Barbora Cellská Jána Grežu a Hora volá Miloša Gontka. ${ }^{9}$

Od nasledujúcej sezóny riaditel' SND Drašar poveril vedením košického divadla Ferdinanda Hoffmanna, ktorý patril k dramaturgicky rozhl'adeným, moderným divadlom ovplyvneným režisérom. Zo svojho ambiciózneho programu (Shakespeare, Hauptmann, Zeyer, Stodola, O'Neill, Wilde, Shaw, Ibsen) stihol realizovat' vel'mi málo, avšak zo siedmich premiér bolo pät’ v slovenčine: z pôvodných hier uviedol Urbánkov Kamenný chodníček, Tajovského novinku Hrdina a rozprávku košického autora Antona Prídavku S Bad’urom je amen, premenil sa v kameň. Ešte pred bratislavskou premiérou plánoval zaradit debut Jána Debnára (pseudonym Janka Borodáča) Chlapci na stráži. Slubnú perspektívu slovenského profesionálneho divadla v Košiciach pretrhli

${ }^{8}$ ŠKODA, J. Niekol'ko čísiel o Východoslovenskom Národnom divadle v Košiciach. In Slovenský východ, 1925, roč. 7, č. 143, s. 5, 26. 6. 1925.

${ }^{9}$ Doterajšia divadelno-historická literatúra medzi premiérami danej sezóny uvádza aj hru Maurica Maeterlincka Modrý vták. Nešlo však o uvedenie tejto hry, ale o pohostinské vystúpenie ruského emigrantského divadla Jaschu Južného (občianskym menom Jakov Davidovič Južnyj) sídliaceho v Berlíne s názvom Modrý vták (Der Blaue Vogel). Išlo o kabaretný typ divadla, v ktorom sa kombinovali ruské l’udové piesne, postupy moderného divadla a satirické skeče. 


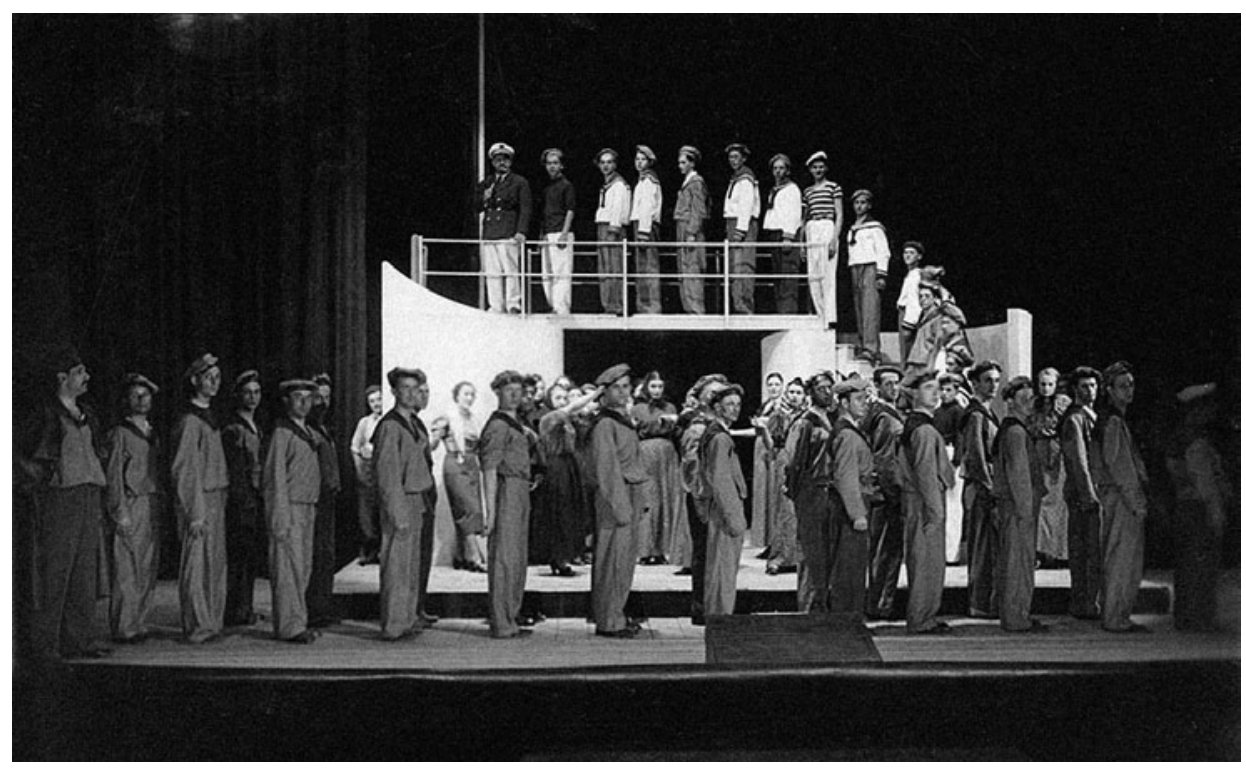

Vsevolod Višnovskij: Optimistická tragédia. Východoslovenské národné divadlo, premiéra 6. 11.1937. Réžia Jaroslav Skála. Foto archív Východoslovenského múzea v Košiciach.

jesenné predvojnové udalosti. Napriek tomu Hoffmann predstavil - slovami teatrologičky Dárie Fehérovej -,,silnú koncepciu európskeho rozmeru, vyváženú z hl’adiska žánru, západo-východnej orientácie, aktuálnosti hier" ${ }^{\prime 10}$.

Počas existencie VND uviedla dramaturgia niekol'ko textov autorov pôsobiacich na východnom Slovensku.V prvom období prevažovala česká dramatika, zaznamenávame aj niekol'ko slovenských autorov (napríklad Tajovský, Urbanovič, Chalupka, Stodola, Urbánek).V celku však išlo o mix lacnej literatúry a kvalitnej inonárodnej dramatiky (Shakespeare, Molière, Madách, Wedekind, Shaw, Ibsen, Wilde, Strindberg, Tolstoj, Gogol', Hauptmann).V druhom období sa divadlo snažilo nahrádzat' nedostatok pôvodnej drámy aspoň uvedením hier preložených do slovenčiny. Medzi prekladatel'mi môžeme nájst' mená vtedajších aj budúcich slovenských hercov a režisérov: Martina Guttmanna (neskôr známeho pod menom Martin Gregor) a Ivana Turza (Miklós László: Drogéria, uvedená pod názvom Parfuméria, 1937), Janka Borodáča (Jens Locher: Vzbura v rodine, 1938) a Martina Hollého (Ferenc Molnár: Dalila, 1938). Česká divadelná vlna priniesla $\mathrm{v}$ dvadsiatych rokoch na východ mladej republiky vplyv pražských skúseností a bratislavskej dramaturgie. Nešlo len o svetovú dramatiku, ale - ako konštatuje divadelná historička Zdenka Pašuthová - „princíp rozširovania overenej dramaturgie sa týkal aj českých a slovenských hier" ${ }^{\prime 11}$. Dramaturgia prvého obdobia VND bola vnútorne diferencovaná a determinovaná umeleckými

${ }^{10}$ FOJTÍKOVÁ FEHÉROVÁ, D. Ferdinand Hoffmann - rozhladený dramaturg. In Ferdinand Hoffmann. Kritik, dramaturg, režisér... (Eds. V. Štefko, D. Fojtíková Fehérová, M. Timko). Bratislava : Divadelný ústav, 2015, s. 208.

${ }^{11}$ PAŠUTHOVÁ, Z. Činoherné divadlo v rokoch 1920 - 1932. In Dejiny slovenského divadla I. Bratislava : Divadelný ústav, 2018, s. 165. 


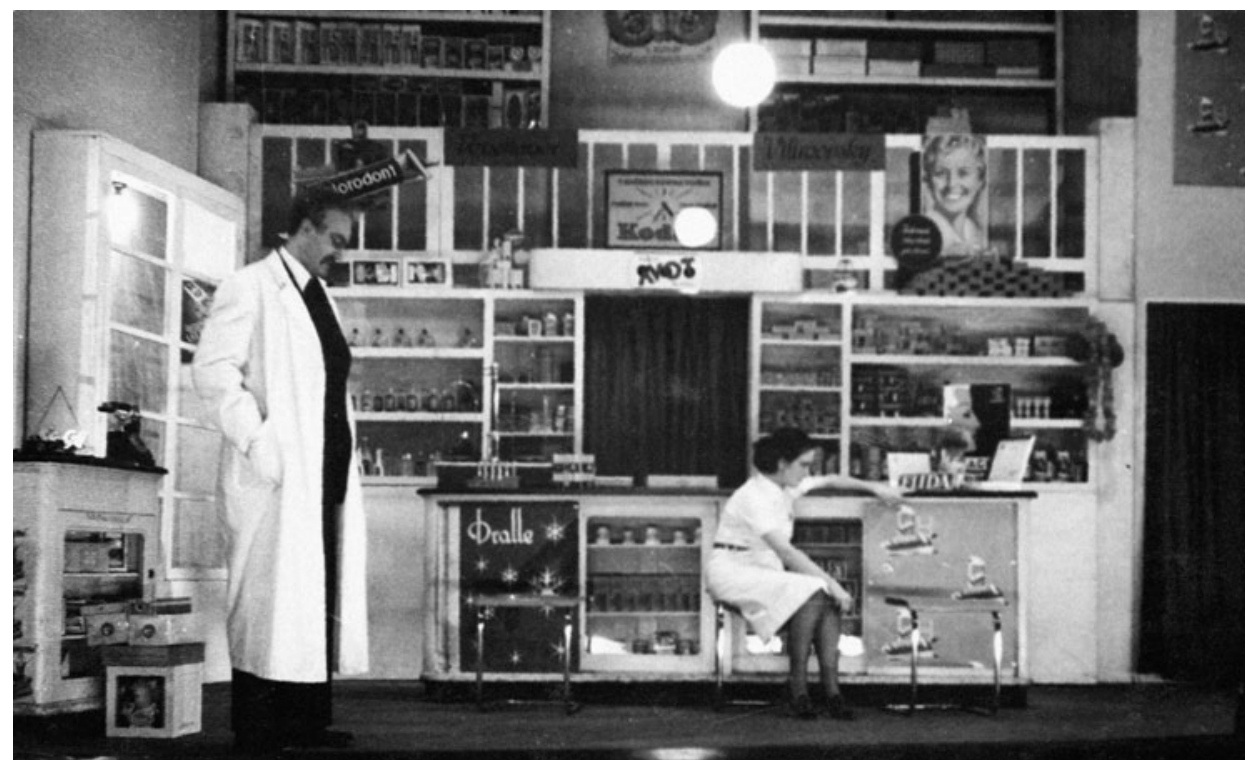

Miklós László: Drogéria (Parfuméria). Východoslovenské národné divadlo, premiéra 27. 11. 1937. Réžia Ivan Lichard. Vlavo Ivan Lichard (Jozef Fábry). Foto archív Východoslovenského múzea v Košiciach.

názormi, vkusom a preferovanými štýlmi riaditel’ov. Druhé obdobie, aj vzhl'adom na jeho krátke trvanie, svedčí viac o tendenciách vedúcich umeleckých osobností.

\section{$1945-1953$}

V roku 1945 vzniklo v Košiciach už po tretíkrát Východoslovenské národné divadlo, tentoraz ako štátna inštitúcia. Riaditel’om sa stal Janko Borodáč a tak ako v činohre SND, aj tu bola dramaturgia odrazom jeho ideovo-estetických preferencií. Umeleckým šéfom činohry, režisérom a v prvých rokoch dramaturgom bol Andrej Chmelko. V začiatkoch bola dramaturgia ovplyvnená vysokým počtom premiér aj absenciou ideovo a umelecky vyhranenej koncepcie, ktorá by mala jasný formotvorný a poetologický ciel'. Prvá činoherná sezóna mala 15 premiér, jasne jej dominoval slovanský repertoár. Išlo o overené tituly vtedajšej doby, o Borodáčovu dramaturgiu v SND a Chmelkovu v Slovenskom divadle v Prešove. Ani nasledujúce sezóny príliš nevybočovali z tejto praxe. Borodáč do Košíc preniesol svoj celoživotný dramaturgický program a Chmelkove prvé tri sezóny mali ambíciu dopĺn̆at ho o pôvodnú tvorbu. V prípade Borodáča možno hovorit’ o konzistentnom postoji, ked’že, ako konštatuje divadelný historik Karol Mišovic, jemu „bol tento dramaturgický rebríček vlastný už od prvej polovice tridsiatych rokov“12.

Prvou Borodáčovou réžiou bol Tajovského Ženský zákon (1945), titul, ktorý interpretačne recykloval zo svojej staršej inscenácie v SND, tak ako pri väčšine dramaturgií

\footnotetext{
${ }^{12}$ MIŠOVIC, K. Náčrt k problematike režijnej a dramaturgickej tvorby Janka Borodáča počas pôsobenia v Košiciach. In Slovenské divadlo, 2019, roč. 67, č. 1, s. 31. DOI: 10.2478/sd-2019-0002.
} 


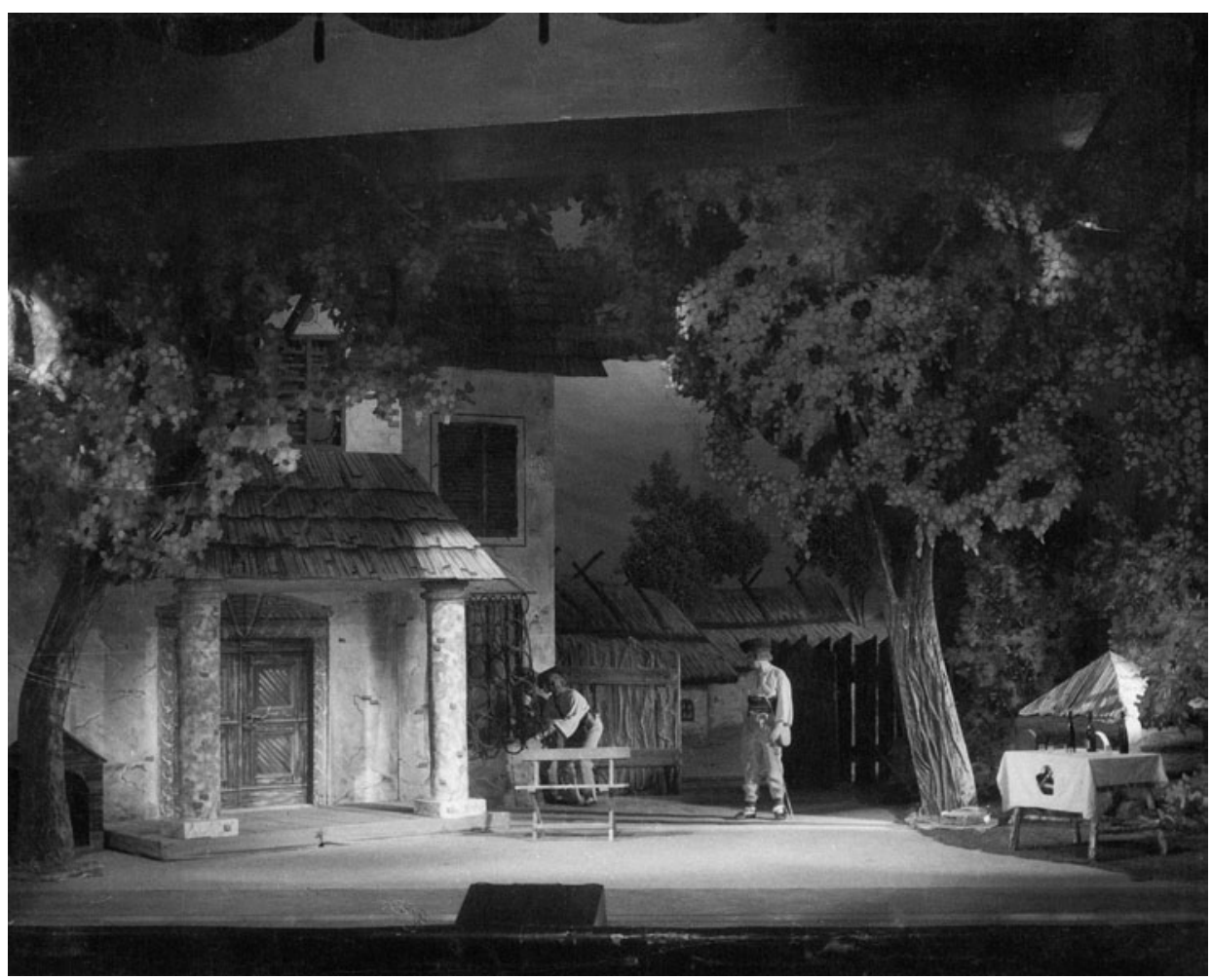

Jonáš Záborský: Najdúch. Národné divadlo v Košiciach, premiéra 3. 5. 1952. Réžia Janko Borodáč. Scéna podl’a návrhov Ladislava Šestinu a Jána Bzdúcha. Foto archív Štátneho divadla Košice. Snímka Karol Rehák.

v prvých košických rokoch. ${ }^{13}$ Zo slovenských autorov, ktorých hry už režíroval, uviedol v celoslovenských premiérach Stodolovu hru Kde bolo, tam bolo (1947) a Žijem cudzí život Hany Zelinovej (1947). Pre Stodolu bol Borodáč vskutku dvorným režisérom, jeho novinka svojím protikomunistickým podtextom nepredstavovala pre Borodáča dramaturgický problém. Aj neskôr dokázal, že jeho lipnutie na realistickej podobe zvulgarizovaného Stanislavského nemusí íst’ ruka v ruke s politickými názormi, ktoré Stanislavského realizmus pretavili do metódy socialistického realizmu. Akákolvek silná viera v javiskový realizmus však Borodáčovi nezabránila pri úpravách hier aktualizovat' dramatické situácie, dokreslit’ charakteristiku postáv dodanými replikami alebo menit mizanscény podl'a požiadaviek doby, a to nielen v SND, ale aj v Košiciach.

V Košiciach Borodáč po prvýkrát inscenoval Strindberga (Vel'ká noc, 1948), zo slovenských autorov Štefana Králika (Posledná prekážka, 1948). Do roku 1949 Borodáč

${ }^{13}$ Boli to Cudzie diet’a Vasilija Škvarkina (1945), Klub gavalierov Michala Baluckého (1946), Lepšie s múdrym plakat', ako s hlúpym skákat' Alexandra Nikolajeviča Ostrovského (1945) v novom preklade Mikuláša Gaceka (Borodáč hru preložil a režíroval v roku 1927 v SND pod názvom Každý múdry je dost’ hlúpy), Shakespearova komédia Mnoho kriku pre nič (1946). 
nerežíroval vel'a, napriek tomu nedosiahol umeleckú koncentrovanost’ a jeho inscenácie, aj ním preverených autorov a hier, neznamenali pre košickú činohru prínos. Tak to bolo aj s jeho profilovými titulmi (Ženský zákon, 1945; prvé košické naštudovanie Najuúcha, 1948; Kocúrkovo, 1949), ktoré, ako píše Karol Mišovic, „zlyhávali na nedostatočnom prevádzkovom zázemí a najmä na nezrelom hereckom ansámbli“14. Po roku 1948 sa Borodáčova pozornost’ opät presunula k overeným titulom. Sú to aj najvýznamnejšie inscenácie jeho košického obdobia: Hviezdoslavova tragédia Herodes a Herodias (1949), Tajovského Statky-zmätky (1950), Záborského Najuúch (nové naštudovanie, 1952), no najmä Čechovove Tri sestry (1952) a Gogol’ov Revízor (1952). Borodáč sa v prvých rokoch akosi automaticky spoliehal na svoje bratislavské skúsenosti, do začiatočníckeho súboru sa snažil implantovat’ vlastný režisérsky štýl, tvrdošijne trvajúc na zle interpretovanej Stanislavského metóde. Svedectvo o tom podáva Mikuláš Štefan Gojda pri hodnotení dvadsiatich rokov Štátneho divadla: „Chcel mat v Košiciach slovenský MCHAT, no spôsoby, ktoré si v MCHAT-e oblúbil, nebolo možné automaticky prenášat na slovenskú klasiku, či na súčasnú tvorbu. ${ }^{\text {15 }}$

Po komunistickom prevrate v roku 1948 sa v dramaturgiách divadiel kládol akcent na uvádzanie slovenskej a ruskej klasiky, sovietskych hier, svetovej klasiky s „progresívnymi“ tendenciami, ale najmä pôvodnej dramatiky. Aj ked' ideologická Dramaturgická a divadelná rada (DDR) vznikla až v roku 1949, nová politická situácia dávala tušit', akým smerom sa budú musiet dramaturgie uberat'. Borodáč ako nekomunista vycítil tlaky nových pomerov, a tak namiesto plánovaného Andreja Chmelka naštudoval k 31. výročiu Októbrovej revolúcie novinku od Leopolda Laholu Štyri strany sveta (1948). No latentný existencializmus hry z tzv. povstaleckej tematiky bol nad jeho sily, s inscenáciou sa trápil, navyše bol cenzorsky prinútený urobit po premiére v hre zmeny. ${ }^{16}$ Ani Chmelkova inscenácia hry Petra Karvaša Bašta (1948), ktorú mal pôvodne režírovat’ Borodáč, nebola umeleckým úspechom.

Tlak politickej moci na dramaturgie divadiel v zmysle preferovania súčasných tém s jasným ideologickým posolstvom sa začal prejavovat’ od sezóny 1949/1950. V nej, popri hrách Kozie mlieko Jána Skalku a Buky podpolianske Štefana Králika, to boli predovšetkým sovietske a ruské tituly. Silnejúca socialistická dramaturgia poznamenala aj nasledujúcu sezónu (L’udia z našej ulice Petra Karvaša, Vítazná porážka Vladimíra Kalytčuka, Kremel'ský orloj Nikolaja Pogodina, Cudzi tieň Konstantina Simonova). V čase vrcholiaceho stalinského despotizmu ohlásila dramaturgia pre sezónu 1952/1953 heslo: „Ešte účinnejšie pomáhat’ na ideologickom fronte pri výstavbe socializmu u nás a v boji za svetový mier!" ${ }^{17}$ Budovatel’skú dramaturgiu predznačila už inscenácia z predošlej sezóny, hra Jaroslava Klímu Št’astie nepadá z neba, zasadená do prostredia železiarní v Kladne. V tomto období prebiehali práce na výstavbe hutného kombinátu pri Košiciach, a tak sa ideovým aj ideologickým pokračovatel’om Klímovej hry mala stat’ agitka z košickej výstavby. Ohlasovanú hru Andreja Zábred-

${ }^{14}$ MIŠOVIC, K. Náčrt k problematike režijnej a dramaturgickej tvorby Janka Borodáča počas pôsobenia v Košiciach, s. 33 .

${ }^{15}$ GOJDA, M. Š. Dvadsat’ rokov činohry ŠD. In ZBOROVJAN, J. a kol. 20 rokov Štátneho divadla v Košiciach. Košice : Východoslovenské vydavatel'stvo, 1965, s. 33.

${ }^{16}$ Išlo o záverečné scénu, v ktorej Borodáč musel nechat’ Yoriku zastrelit nemeckého vojaka. Tak sa Štyri strany sveta stali „hrou socialisticko-realistickou“. CHMELKO, A. Spoza opony. Vydal A. Chmelko, 1996, s. 50

${ }^{17}$ Dramaturgický plán ND v Košiciach na sezónu 1952-53. In Nikolaj Vasilievič Gogol’ : Revízor [Bulletin k inscenácii]. Košice : Národné divadlo v Košiciach, 1952, s. 11. 


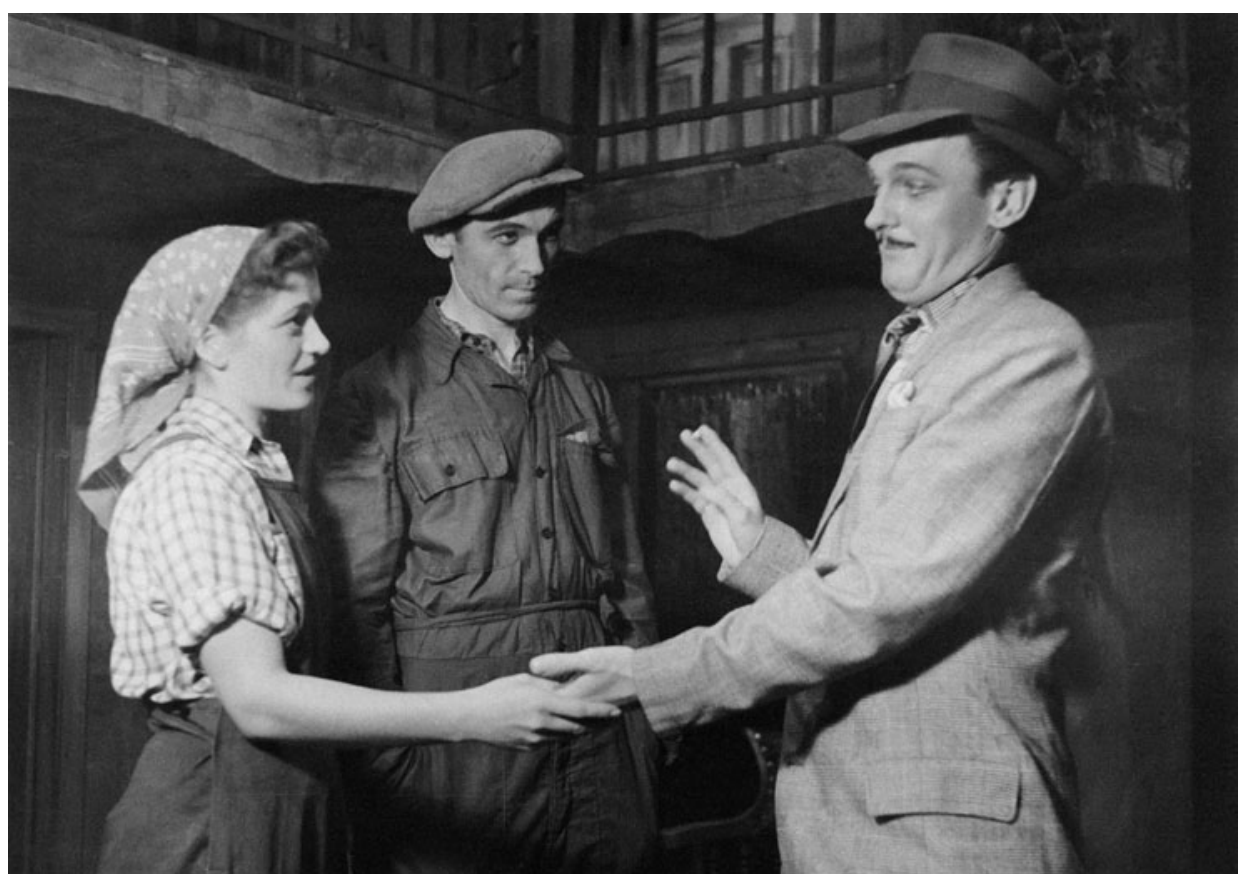

Peter Karvaš: Ludia z našej ulice. Národné divadlo v Košiciach, premiéra 6. 10. 1951. Réžia Andrej Chmelko. Júlia Čunderlíková (Betka), Vladimír Petruška (Matej Struhár), Eduard Bindas (Dubec). Foto archív Štátneho divadla Košice.

ského Druhá smena však nahradila iná agitka, dramatický debut Ladislava Mňačka Mosty na východ. Už nie výstavba železiarenskej huty, ale železničnej trate poslúžila dramaturgii vyhoviet’ straníckym direktívam o budovaní novej spoločnosti a nového človeka. Režisérovi inscenácie, hercovi Vladimírovi Petruškovi, pripadla v tejto sezóne aj hra východonemeckého dramatika Paula Herberta Freyera Stratená hliadka, „zachytávajúca hrdinský boj vietnamských vlastencov za svoju slobodu a nezávislost" "18, ktorou dramaturgia naplnala d’alší povinný autorský a tematický okruh, hry autorov z tzv. l'udových demokracií.

Medzi premiérami ohlasovanými pre túto sezónu zaujme Borodáčova hra Jánošík. Borodáč sa už v roku 1949 zaoberal myšlienkou upravit’ svoju hru Juro Jánošík z konca tridsiatych rokov (uviedol ju v roku 1939 v SND pod pseudonymom Ján Debnár). Motiváciou mu boli predpisy DDR obnovit klasikov, respektíve historické témy z národných dejín podla nových ideových požiadaviek. Takýto prístup k tvorbe repertoáru bol Borodáčovi cudzí a považoval ho za mechanický: ,Z klasikov 3 obnovit nimi predpísaným spôsobom je výroba á la Bata. (...) Celý tento recept je d’aleký umeniu a tvorbe. " ${ }^{19}$ Borodáč sa Jánošíkom zaoberal do konca svojho košického pôsobenia.

${ }^{18}$ Tamže.

${ }^{19}$ List J. Borodáča J. Zborovjanovi z 24. 11. 1949. Uložené v Literárnom archíve Slovenskej národnej knižnice v Martine. Fond Julo Zborovjan, ev. č. 2828. 
Ešte vo februári 1953 v jednom z listov spomína, že pracuje na hre. ${ }^{20}$ Jánošík sa však na profesionálne javisko už nikdy nedostal.

Prvé košické sezóny Andreja Chmelka boli determinované jeho umeleckým pôsobením v prešovskom Slovenskom divadle (1944 - 1945, riaditel', režisér, dramaturg), kde sa v niekol'kých inscenáciách pokúsil zbavit popisného realizmu, čomu zodpovedala aj jeho dramaturgická vol'ba (Králik: Trasovisko, 1944; Max Halbe: Prúd, 1944). V Košiciach sa v prvých rokoch pokúšal dramaturgicky „osamostatnit“”. V septembri 1945 v rýchlom slede inscenuje otváraciu Marínu Havranovú Ivana Stodolu a Kristínu Paula Géraldyho. K Stodolovi pristúpil s realistickou „pietou“, v Kristíne naznačil inklináciu k symbolistickej réžii, s príklonom k poetizmu. S dramaturgickou preferenciou k súčasným dramatickým textom sa zhost’uje aj novinky Júliusa Barča-Ivana Veža (1947). Ešte nedokončenú hru zaradil do dramaturgického plánu, „len čo autor naznačil jej obsah a ideové zameranie“21, a v príbehu vycítil biblické presahy do súčasnosti. Popri Veži uviedla košická činohra do roku 1948 niekol'ko d’alších pôvodných hier v celoslovenských premiérach. Takou bola i Karvašova Hra o básnikovi (1946) v Chmelkovej réžii. Vytváranie ideovo-estetických a poetických protiváh k Borodáčovej dramaturgii potvrdil aj v inscenáciách hier Petra Zvona Tanec nad plačom (1946) a Luigiho Pirandella Hl'adaj seba (1948).

Prvé tri sezóny činohra nemala interného dramaturga. Spisovatel’ a básnik Julo Zborovjan vykonával od roku 1945 funkciu tajomníka činoherného súboru s povinnostou zostavovat’ a redigovat’ bulletiny všetkých súborov. Až od sezóny 1948/1949 sa stal dramaturgom činohry, jeho umelecké predstavy je však popri dramaturgicko-režijných preferenciách dvojice Borodáč-Chmelko tažké identifikovat'. Zborovjanova pozícia pri dominantnom Borodáčovi a Chmelkových režisérskych ambíciách nebola totiž jednoduchá. Obmedzovala sa na komplementárnu dramaturgiu, ktorá pri vel'kom počte premiér $\mathrm{v}$ podstate iba vyvažovala režisérske priority vedúcich osobností. Nie u všetkých dramaturgií, pod ktoré sa Zborovjan podpísal, je možné jednoznačne určit', či boli výsledkom jeho autonómneho rozhodnutia a do akej miery ich determinovali ideové a estetické názory vedenia činohry a divadla. K ním presadeným dramaturgiám môžeme s istotou zaradit najmä rozprávky, ktoré - často pod pseudonymom - prekladal, upravoval alebo sám napísal. ${ }^{22}$ Borodáčove ani Chmelkove réžie neprechádzali výraznejším sitom dramaturgie, skôr sa od nich odvíjali d’alšie tituly. V lepšom prípade Borodáč korigoval ním navrhnuté hry, avšak pri zachovaní tak autorskej a nacionálnej, ako aj žánrovej a poetologickej preferencie.

Popri Borodáčovi a Chmelkovi režírovali herec František Greguš a v prvých dvoch sezónach aj Dezider Janda, no t’ažisko ostávalo na prvých dvoch menovaných. Greguš inscenoval najmä vlastné rozprávky. Inklinoval ku komediálnym žánrom, a tak mu Borodáč s Chmelkom zverili aj dramaturgiami divadiel ideologicky protežované Kozie mlieko. Po roku 1947 dokonca inscenoval niekol'ko profilových svetových klasických komédiografov, medzi inými Molièra (Don Juan, 1947; Scapinove šibalstvá, 1948;

${ }^{20}$ Žiadost’ o príspevok na opravu zubov. [List J. Borodáča Okresnému ústavu národného zdravia v Košiciach z 3. 2. 1953]. Uložené v Štátnom archíve v Košiciach, Fond Štátne divadlo v Košiciach (1900) 1945-1995, osobný spis J. Borodáča, inv. č. 394.

${ }^{21}$ CHMELKO, A. S Barčom do tretej sezóny. In Július Barč Ivan : Veža [Bulletin k inscenácii]. Košice : ND v Košiciach, 1947, s. 8.

${ }_{22}$ Čarovná bylinka, 1946; Koza rohatá, 1951; Snehová královná, 1949; O troch Číñankoch, 1950; Lasica, 1954. 
Učené ženy, 1951) a Goldoniho (Sluha dvoch pánov, 1953). Po tom, čo Janko Borodáč opustil Košice, Greguš, ktorý s ním v roku 1945 prišiel zo SND, prestal režírovat'. Je otázne, do akej miery to bol dôsledok straty umeleckého tútora a do akej miery následok toho, že sa „usiloval uplatňovat’ niektoré novátorskejšie prvky syntetickejšie poňatej divadelnej štylizácie a niektoré divadelné postupy, exponované najmä v niektorých komediálnych inscenáciách, sa v názoroch a atmosfére prvej polovice pät'desiatych rokov označili dokonca za formalistické ${ }^{\prime 23}$. Na rozdiel od Greguša, ktorý si vydobyl určitú pozíciu, Janda neustál dramaturgickú dominanciu a jednostrannú poetologickú vyhranenost' dvojice Borodáč - Chmelko. Počas dvoch košických sezón sa dostal len ku komediálnym žánrom. ${ }^{24}$

Do roku 1948 Chmelko realizoval vlastný dramaturgický program. Borodáč-budovatel' v prvých rokoch nedosahoval výraznejšie inscenačné výsledky, pohyboval sa „dost' na pokraji popisného realizmu, ba nebol skúpy ani na prvky naturalizmu. “25. Po roku 1948 je jeho dramaturgicko-režijný program presvedčivejší. Chmelko uprel svoju pozornost' k svetovej dramatike (Shakespeare: Skrotenie zlej ženy, 1949; Ostrovskij: Talenty a ctitelia, 1951; Molière: Tartuffe, 1952; Kleist: Rozbitý džbán, 1954), k vydarenejším inscenáciám však patrili iba Eugénia Grandetová Honoré de Balzaca (1954) a Chirurg Platon Krečet Alexandra Kornijčuka (1955). Iniciatívnym bol pri dramaturgii angažovaných, až schematických textov, čo potvrdil aj vlastnou budovatel'skou hrou Po širokej kol’aji (1950). V pät’desiatych rokoch ignoroval nastupujúce moderné prúdy v divadle, jeho dramaturgia stratila umeleckú ambíciu a, ako konštatuje divadelný historik Ján Jaborník, v jeho réžiách sa začali „objavovat aj niektoré znaky dobových zjednodušujúcich tendencií uplatňovania socialistického realizmu“26.

Tak ako v medzivojnovom období, aj po roku 1945 sa košická dramaturgia snažila nadviazat’ spoluprácu s miestnymi spisovatel'mi. Tentoraz však boli výsledkom hry-ideologémy v schematickej forme (k už spomínaným sa zaradila i d’alšia Skalkova hra, Krompašská vzbura, 1956). Požiadavku uvádzania pôvodnej drámy chcela dramaturgia dosiahnut aj úpravami a dramatizáciami. V tomto smere bol najiniciatívnejší literárne ambiciózny Andrej Chmelko. Pre potreby košického divadla upravil hru Martina Kukučína Bacúchovie dvor (1949) a zdramatizoval novelu Boženy Slančíkovej-Timravy Hrdinovia (1953), ktorú motivicky „obohatil“ o d’alšie autorkine prózy a predvojnový príbeh posunul až do roku 1918.

Osobitnú kapitolu predstavujú úpravy Janka Borodáča, často idúce za pôvodný fabulačný rámec a niekedy aj nad ideovo-estetický zámer autora. U Borodáča išlo, najmä v prípade slovenskej klasiky, o dramaturgický princíp. Ako už bolo konštatované, Borodáč napriek konzistentnosti vo svojich dramaturgických názoroch a režijnom štýle často pristupoval k úpravám v súlade s dominantným politickým, resp. ideologickým smerom. Najvýraznejšie úpravy previedol v dráme Herodes a Herodias.

\footnotetext{
${ }^{23}$ JABORNÍK, J. Tridsatpät rokov činohry. In 35 rokov Štátneho divadla v Košiciach. (Ed. Š. Fejko.) Košice : Štátne divadlo, 1980, s. 7.

${ }^{24}$ Marcel Achard: Život je krásny (1946), Victor Eftimiu: Človek, ktorý videl smrt' (1946), George Bernard Shaw: Katarína vel’ká (1946), Milan Begovič: Návšteva v Splite (1947), Stefan Lazarov Kostov: Velikáš (1947).

${ }^{25}$ GOJDA, M. Š. Dvadsat’ rokov činohry ŠD. In ZBOROVJAN, J. a kol. 20 rokov Štátneho divadla v Košiciach, s. 32 .

${ }^{26}$ JABORNÍK, J. Tridsatpät rokov činohry. In 35 rokov Štátneho divadla v Košiciach. (Ed. Š. Fejko), s. 6. K umeleckým koreláciám Borodáča a Chmelka pozri HIMIČ, P. Janko Borodáč - Andrej Chmelko. Dve cesty - jeden smer. In Slovenské divadlo, 2019, roč. 67, č. 1, s. 40 - 57. DOI: 10.2478/sd-2019-0003.
} 
Vyškrtol celé druhé dejstvo a niektoré výstupy personálne zoštíhlil, čím ochudobnil dej. Podstatným znakom dramaturgickej koncepcie bolo príbeh aktualizovat', zvýraznit’ jeho sociálny (politický) podtext, či, slovami Karola Mišovica, odhalit’ „dejovú štruktúru charakteristickú pre hry socialistického realizmu - spravodlivým hnevom planúci burič [Jochanan, pozn. P. H.], ktorý obetuje vlastný život za lepšie zajtrajšky svojej spoločenskej triedy“27. Takéto aktualizácie v období po roku 1948 neboli len doménou Borodáča a košickej dramaturgie, ale československého divadla ako celku.

Členenie na slovenský repertoár (tak klasické ako aj súčasné hry), slovanskú (najmä ruskú a sovietsku) dramaturgiu a svetový repertoár, s akcentovaním progresívnych ideových, ba aj ideologických čŕt, si našlo svoje miesto už v prvých rokoch existencie divadla, nie až po vzniku Dramaturgickej a divadelnej rady. Prvá košická činoherná dekáda má takto z hl'adiska tematických a ideovo-estetických dramaturgických okruhov homogénnu podobu, po roku 1948 s pridanou ideologickou hodnotou. Práve slovenská klasika mala byt základom, ktorý „nedovolil odbočovat’ a naprázdno experimentovat’ $\mathrm{v}$ dramaturgii za formalistickými a dekadentnými bezúčelnost’ami“ ${ }^{28}$. Silný akcent pretrvával nad’alej na ruskej klasike, ktorú preferoval najmä Borodáč. Ideologické sovietske hry a dramatici z tzv. l’udových demokracií boli zase Chmelkovou doménou. Faktom však ostáva, že popri takto orientovanej dramaturgickej stratifikácii sa v sledovanom období objavujú aj hry Shakespeara, Molièra, Goldoniho a Shawa. Silný zástoj mali českí dramatici (Josef Kajetán Tyl, Alois Jirásek, Ladislav Stroupežnický) a rozprávky. No napriek zdaniu vyváženosti ide skôr o eklektickú dramaturgiu ako výsledok režisérskych (poetologických, interpretačných, štýlových) preferencií, čím bola prvá dekáda košickej činohry „ochudobnená o modernú, progresívnu, vývinotvornú líniu“29. Išlo o dôsledok absencie autonómnej dramaturgie, reprezentovanej silnou, na umeleckom vedení divadla nezávislou osobnostou. Navyše, ako to v polovici šest’desiatych rokov konštatoval Gojda, „Chmelkovou chybou je, že si - tak ako Borodáč - nevolí diela najvhodnejšie, že často k inscenovaniu hry ho vedie pieta a úcta $\mathrm{k}$ autorovi, k národnej kultúre“ ${ }^{\prime 30}$. Kým však Borodáč po celý čas formoval súbor umelecko-pedagogicky, Chmelko postupom času viac či menej ideovo-ideologicky.

\section{$1954-1963$}

Borodáčova a Chmelkova dramaturgická a režisérska dominancia mala za následok umeleckú stagnáciu košickej činohry. Po Borodáčovom odchode do Bratislavy (1953) sa javilo byṫ nevyhnutným nájst’ režisérsky pendant k novému riaditelovi Chmelkovi. Je potrebné poznamenat', že Chmelko sa snažil obsadit uvolnený post umeleckého šéfa činohry silnou režisérskou osobnostou, na jeho ponuky však žiadny kandidát nereflektoval. Východiskom z núdze bol herec Jozef Hodorovský, ktorý v poslednej Borodáčovej sezóne redigoval niektoré bulletiny namiesto dlhodobo cho-

\footnotetext{
${ }^{27}$ MIŠOVIC, K. Náčrt k problematike režijnej a dramaturgickej tvorby Janka Borodáča počas pôsobenia v Košiciach, s. 34 .

${ }^{28}$ ZBOROVJAN, J. Informatívne o činohre. In Národné divadlo v Košiciach : Jubilejné číslo programu ND $v$ Košiciach, s. 40.

${ }^{29}$ JABORNÍK, J. Minulost’ a prítomnost’ košickej činohry. In Slovenské divadlo, 1973, roč. 21, č. 3, s. 307.

${ }^{30}$ GOJDA, M. Š. Dvadsat' rokov činohry ŠD. In ZBOROVJAN, J. a kolektív. 20 rokov Štátneho divadla v Košiciach, s. 35.
} 
rého Jula Zborovjana. Ten dokonca v čase premiéry Revízora požiadal o rozviazanie pracovného pomeru a do divadla sa vrátil až v novej sezóne, po Borodáčovom odchode. Hodorovský už za Borodáčovej éry režíroval rozprávky. V tomto repertoári pokračoval aj ako autor, neskôr režíroval estrádne ladené silvestrovské pásma, na niektorých autorsky spolupracoval. Ako umelecký šéf si „pridelil“ i niekol'ko kvalitných titulov (Hollý: Gel’o Sebechlebský, 1954; Čechov: Pytačky - Konské priezvisko - Medved', 1954, v spoluréžii s Eduardom Bindasom; Zapolska: Morálka pani Dulskej, 1954; Čapek: Lúpežník, 1955; Molière: Lekárom proti svojej wôli, 1956).

Pri hodnotení vývojových tendencií by nebolo správne nevšímat si zárodky pohybov, ktoré naznačujú odklon od dovtedajšieho dramaturgického uvažovania. Za takýto náznak možno považovat' druhú Hodorovského sezónu v pozícii umeleckého šéfa (1954/1955), ktorú už plne pripravoval Zborovjan. Z jedenástich premiér činohra popri troch rozprávkach a hrách pre deti uviedla Morálku pani Dulskej, Eugéniu Grandetovú, Dobrodružstvo pri obžinkoch, Othella, Lúpežníka. Aj ked' slovenská teatrológia zmeny v dramaturgicko-inscenačnom smerovaní po Borodáčovom odchode spája s príchodom režisérky Magdy Husákovej-Lokvencovej a neskôr s nástupom dvojice režisérov Ota Katušu a Jozefa Palku, faktom je, že už spomínaná sezóna bola prvou, v ktorej sa Zborovjan pokúsil oslobodit’ od dovtedajšej Borodáčovej a Chmelkovej dominancie. Uvedomoval si absenciu výraznej režisérskej osobnosti, preto pozval hostujúcich režisérov Jozefa Budského (Othello), Dezidera Jandu (Dobrodružstvo pri obžinkoch) a Ota Katušu (Csizmarekova komédia Skrývačka), čo možno vnímat’ ako snahu narušit ustálené interpretačné a inscenačné šablóny.

Nástup Magdy Husákovej-Lokvencovej nepochybne zasiahol do stojatých košických vôd. Výnimočnou bola jej úzka spolupráca so Zborovjanom na novej dramatizácii Kalinčiakovej Reštavrácie (1955). ${ }^{31}$ Pre režisérku išlo o návrat do divadla, po nútenom odchode z bratislavskej Novej scény. Aj ked' javisková podoba sa niesla v tradičnom štýle, opierajúc sa o „zovretý, prísne realistický tvar “32 dramatizácie, režisérka nepodlahla ideologizujúcim tendenciám doby. Ako pokračuje Ján Jaborník, „Do tohto dramatického tvaru sa mu [Zborovjanovi, pozn. P. H.] podarilo premyslene a vcelku výstižne vtesnat všetko podstatné z Kalinčiakovho porozvetvovaného epického rozprávania“33. Ibsenova Hedda Gablerováa ${ }^{34}$ a Suchovo-Kobylinova hra Krečinskij sa žení, ktoré Husáková-Lokvencová režírovala vo svojej jedinej košickej sezóne (1955/1956), boli tiež realistickými inscenáciami, ale opät bez nadužívania ideológie, aj ked’s nutnou dávkou vtedajšej charakteristiky „prehnitej“ buržoáznej spoločnosti.

Pôsobenie Husákovej-Lokvencovej v Košiciach i hostovanie Budského predstavovali prvé prieniky nového dramaturgického a interpretačného myslenia. Zborovjanov dramaturgický plán ukazuje, že spomínané dve sezóny môžeme považovat’

${ }^{31}$ Pozri BOBOK, J. Kalinčiakova „Reštavrácia“ na scéne Štátneho divadla v Košiciach (Poznámky k dramatizácii a k inscenácii). In Slovenské divadlo, 1956, roč. 4, č. 2, s. 148 - 159.

32 JABORNÍK, J. Košická sezóna Magdy Husákovej-Lokvencovej (1955 - 1956). In LINDOVSKÁ, N. Magda Husáková-Lokvencová : próa dáma slovenskej divadelnej réžie. Bratislava : Divadelný ústav, Vysoká škola múzických umení, Divadelná fakulta, 2008, s. 134.

${ }^{33}$ Tamže.

${ }^{34}$ Pôvodne bola zaradená Ibsenova hra Strašidlá, ktorú presadzoval Zborovjan. Komunistická cenzúra však inscenovanie tejto hry zakázala. Režisérka tak „upustila“ od jej inscenovania „po dohovoroch na Povereníctve kultúry, na návrh súdruha Slivku“. Pozri List Dr. M. H. Lokvencovej riaditelovi ŠD v Košiciach zo dňa 27. 1. 1956. Uložené v Štátnom archíve v Košiciach, Fond Štátne divadlo v Košiciach (1900) 1945-1995, osobný spis M. Husákovej-Lokvencovej, inv. č. 394. 


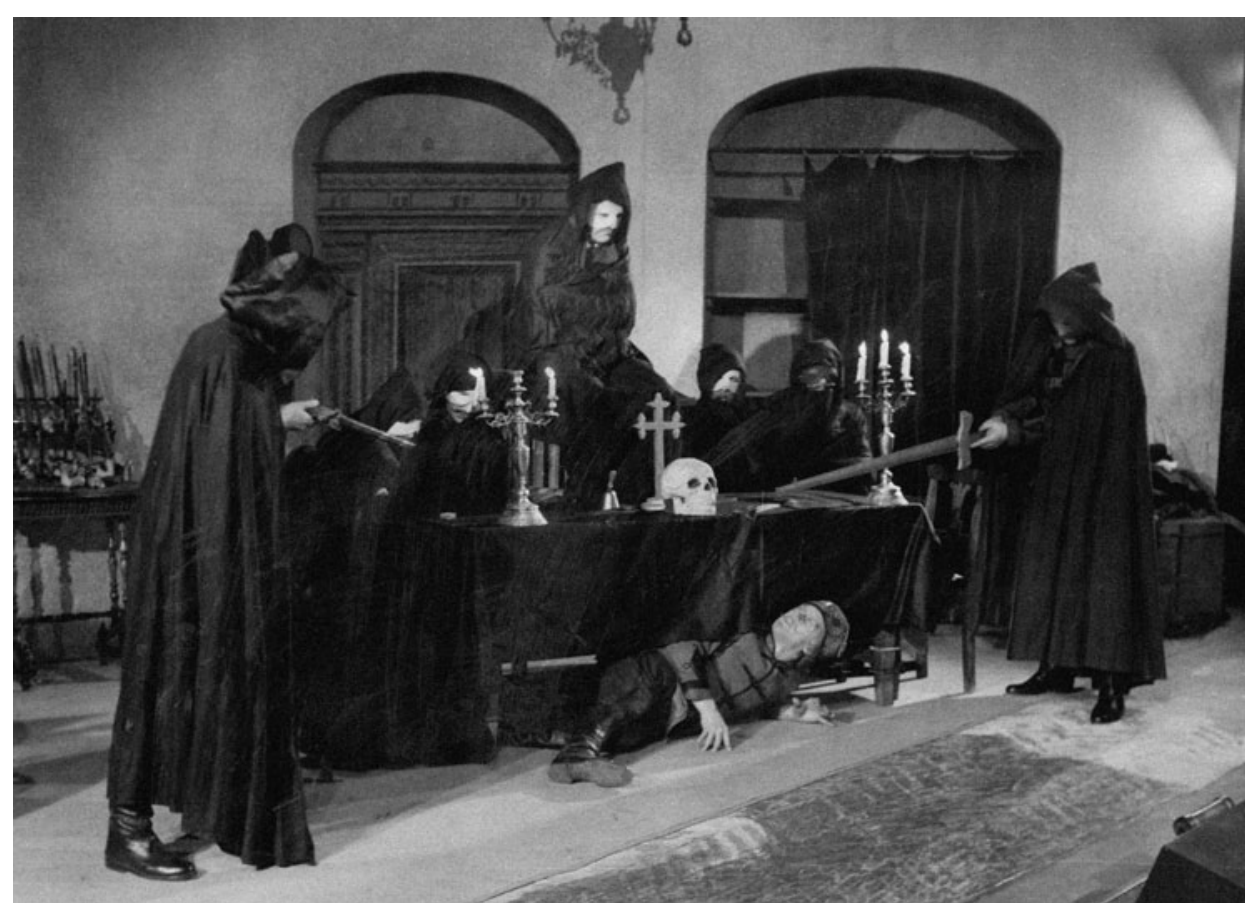

Ján Kalinčiak - Julo Zborovjan: Reštavrácia. Štátne divadlo Košice, premiéra 17. 12. 1955. Réžia Magda H. Lokvencová. Výstup Súd nad Matiášom Bešeňovským. Foto archív Štátneho divadla Košice.

za jeho prvé autonómne obdobie v pozícii dramaturga. Od sezóny 1955/1956 sa stal umeleckým šéfom činohry herec Ján Bzdúch, avšak až nástup dvojice režisérov Ota Katušu (1956) a Jozefa Palku (1957) znamenal prvý významnejší prienik novej ideovo-estetickej a umelecko-formálnej platformy, intenzívnejšieho prepojenia dramaturgických a režijných uvažovaní.

Predznamenala to už prvá Katušova inscenácia v internom stave, Rollandova Hra o láske a smrti (1956). Premiéra sa konala „v čase vrcholiacej fázy mad’arských revolučných udalostí“, v takomto politickom kontexte nanajvýš aktuálne „rezonovali slová Courvoisiera o girondistoch a jakobínoch“. ${ }^{35}$ V prvej sezóne Katuša režíroval ešte Goldoniho Starého frfloša a Shakespearovu komédiu Ako sa vám páči, teda tituly, ktoré po období inscenačnej šedivosti umožňovali opätovne rozohrat’ pestrú paletu komediálneho a živelného herectva (tu sa ponúka paralela so Zacharovou inscenáciou Shakespearových Veselých paní z Windsoru v SND, 1954).

Jozef Palka po svojom nástupe (najmä však po prevzatí vedenia súboru) vyčleňoval Katušovo pole pôsobnosti stále viac smerom ku komediálnym žánrom. Ten túto tendenciu potvrdil niekol'kokrát, napríklad Stodolom (Jej proý ples, 1958) ${ }^{36}$, Carlom Gozzim (Turandot, 1961),Tylom (Strakonický gajdoš, 1961), Goldonim (Rozmarná žena,

${ }^{35}$ FERKO, T. Skice o košickej činohre v jubilejnom formáte. In Slovenské divadlo, 2016, roč. 64, č. 1, s. 69.

${ }^{36}$ Pôvodne ide o komédiu Posledná symfónia (1930), ktorú autor prepracoval v roku 1953. V Košiciach sa uvádzala jej druhá verzia z roku 1957. 


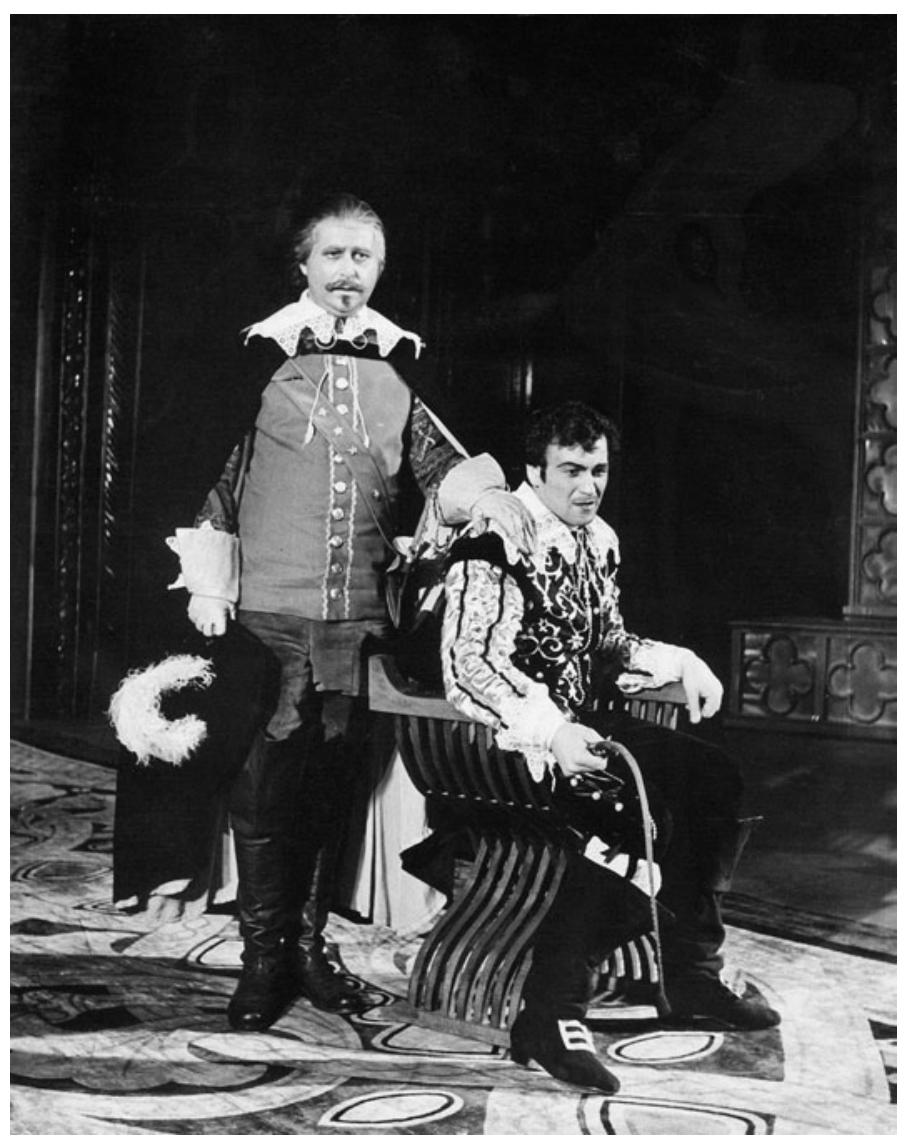

Juraj Váh: Bohovia Amsterdamu. Štátne divadlo Košice, premiéra 21. 2. 1959. Réžia Jozef Palka. Ján Bzdúch (Kapitán Duin), Ivan Rajniak (Ján Pieter). Foto archív Štátneho divadla Košice. Snímka Mária Litavská.

1962), Ludvikom Aškenazym (C. k. štátny ženích, 1963), na opačnom póle ju vyvážil Michailom Jurievičom Lermontovom (Maškaráda, 1959), Arturom Millerom (Smrt’ obchodného cestujúceho, 1960), Maxom Frischom (Andorra, 1963). Zaradenie Millera a Frischa poukazuje na značný odklon od dovtedajších ideových dominánt, zadefinovaných v období schematizmu.

Začiatok Palkovho košického obdobia priam symbolicky rámcuje Chmelkova inscenácia hry Nikolaja Pogodina Muž s puškou (1957). Bola to nadlho posledná hra z tohto ideového a tematického okruhu. Naopak, Palkova dramaturgia smerovala k anglickej klasickej dramatike (Shaw: Pekelník, 1958; Shakespeare: Veselé panie z Windsoru, 1959; Hamlet, 1962; Večer trojkrálový, 1963), k českej modernej dráme (Čapek: R. U. R., 1958; Biela nemoc, 1961), no najmä k pôvodnej tvorbe. Košická činohra uviedla v danom období niekol'ko hier súčasných slovenských autorov. Palka inscenoval Bohov Amsterdamu Juraja Váha (1959), Vlak nečaká Juraja Severa (1960), hry L’udovíta Filana A bolo svetlo (1961) a Motýle (1962), Búrlivé leto L'ubomíra Smrčka a Juraja Špitzera (1959), Chmelko naštudoval Karvašovo Zmŕtvychvstanie deduška Kolomana (1961). Pri menšom počte réžií inscenuje Chmelko aj slovanskú klasiku (Ženský zákon, 1959; Ujo Ván̆a, 1960; Radúz a Mahuliena, 1963). 
Pri hodnotení Palkovho košického obdobia (1957 - 1963) je z pohl’adu analyzovanej témy dôležitý zástoj dramaturgičky Margity Mayerovej (1956 - 1963), absolventky bratislavskej Divadelnej fakulty Vysokej školy múzických umení. Bolo to po prvýkrát, ked’ boli v košickej činohre dvaja interní dramaturgovia. Služobne starší Zborovjan mal stále dôležité slovo pri zostavovaní repertoáru. Aj ked’ Palka staval svoj režisérsky program na úzkej spolupráci s Mayerovou, podrobná identifikácia dokazuje, že nie všetky jeho inscenácie sú výsledkom jej práce. Mayerovej príchod do Košíc totiž aktivizoval a do istej miery oslobodzoval aj Zborovjana. Ten popri tradičnej spolupráci s Chmelkom (Karvaš, Čechov) dramaturguje Palkovi napríklad Búrlivé leto, Arbuzovov Príbeh na brehu rieky (1960) ako „drámu optimizmu“, z režisérových výraznejších inscenácií $R$. U. R.. Jasná inklinácia Margity Mayerovej k súčasným a univerzálnym témam, $\mathrm{k}$ ideovej nosnosti dramatického diela, $\mathrm{k}$ dramaturgii ako formotvornej zložke javiskového celku, so zameraním na rozvíjanie moderného herectva a réžie, sa ukázala najmä v Palkových inscenáciách hier Váha, Čapka (Biela ne$m o c)$, Filana ( $A$ bolo svetlo). Tým mu umožňovala umelecky presvedčivejšie realizovat jeho program. $\mathrm{V}$ ňom rušivo vyčnieva ich spoločné autorské pásmo poézie $\mathrm{k} 40$. výročiu vzniku Komunistickej strany Československa L’ud báseň hovorí (1961), ktoré síce možno chápat’ ako povinnú daň režimu, no obsahom aj javiskovou realizáciou pôsobí na začiatku šesťdesiatych rokov značne anachronicky. Mayerová dramaturgovala aj niekol'ko Katušových inscenácií (napríklad Strakonický gajdoš a Maškaráda), medzi nimi i vlastný preklad súčasnej komédie Vratislava Blažeka Príliš Štedrý večer (1960), satiry na „kádrovací mechanizmus“, avšak stále v línii socialistických poučení.

Práca so súčasnými dramatikmi patrila k Mayerovej dramaturgickým prioritám. Aj prostredníctvom ich hier sa v období prvých polemík s metódou socialistického realizmu snažila prinášat témy, ktoré by svojou univerzálnou výpoved’ou smerovali k aktuálnej a širšej skutočnosti. Tak ako v prípade Bohov Amsterdamu, kde historické pozadie príbehu nezakrývalo vnútorný konflikt hlavného hrdinu, ktorý je "slobodným človekom, nemá vlastníckych a majetníckych pocitov, (...) je svojím spôsobom myslitel” (.... ${ }^{\prime 37}$. Navyše pre dramaturgičku „,v pôvodnej slovenskej dramatike zaznel Váhovou hrou nový tón, inšpirovaný nesporne brechtovskou dramaturgiou“38. Posledná premiéra v záverečnej Palkovej košickej sezóne, Chmelkova realisticky uchopená inscenácia Kvetnatej cesty (1963), hry Borodáčovho oblúbeného sovietskeho satirika Valentyna Katajeva, akoby predznamenávala koniec ucelenejšej snahy mladých tvorcov posunút' interpretačné možnosti súboru smerom k modernému divadelnému jazyku.

Margita Mayerová predstavuje v dejinách košickej činohry osobnost’ artikulujúcu umelecký program, ktorý sa opieral o nové a moderné divadelné prúdy. Po študijnej ceste slovenských divadelníkov do Zväzu sovietskych socialistických republík (1957), kde popri MCHAT-e videla aj predstavenia divadiel Vachtangova, Majakovského či Divadla satiry, reflektuje snahu súčasného diváka objavovat’ nové javiskové formy a nových autorov. Mayerová ich na začiatku svojho košického pôsobenia videla ešte na platforme realizmu, v ktorom však už „odpadajú nejasné a nevýstižné formulky, ktoré zužovali náplň tohto pojmu výlučne na utilitárnu stránku pedagogických a su-

\footnotetext{
${ }^{37}$-mm-. [M. Mayerová] Bohovia Amsterdamu - história či prítomnost'? Juraj Váh : Bohovia Amsterdamu [Bulletin k inscenácii]. Košice : Štátne divadlo, 1959, s. 3.

${ }^{38}$ Tamže.
} 
cho ideových proklamácií “39. Istým spôsobom sa týmto vyrovnáva aj s Borodáčovým zúženým chápaním Stanislavského, ved’ jeho metóda „nie je akási dopredu určená neomylná schéma, či už sústava znakov, ktorá sa dá pri mechanickom prijímaní bez straty svojej podstaty ,našit" na ten alebo onen súbor" ${ }^{\text {"40 }}$. V kooperácii so Zborovjanom Mayerová zároveň zvýrazňovala umeleckú svojbytnost' inštitucionalizovanej dramaturgie, v akceptovaní a úzkom prepojení na funkcie tzv. prevádzkovej dramaturgie.

\section{$1963-1970$}

Slovenská teatrológia zhodne označuje druhú polovicu šest’desiatych rokov v košickej činohre ako obdobie improvizácií, povrchnosti, paberkovania, pretrvávania. V zložke dramaturgickej, režijnej aj hereckej. Slovenské divadlá v danom období zastihla aj divácka kríza. Na stránkach novín a časopisov prebiehali diskusie o adekvátnosti a zmysluplnosti divadelnej siete, presadenej a realizovanej po druhej svetovej vojne Andrejom Bagarom, o novej západoeurópskej a americkej dráme, o konfrontácii staršej a mladšej hereckej i režisérskej generácie a podobne. Spomínané problémy a témy sa vyhranenejšie než v iných slovenských divadlách prejavili práve v Košiciach.

Nástup nového umeleckého šéfa, režiséra Milana Bobulu (1963), predstavoval nádej nadviazat' na úspešné obdobie z prelomu desatročí. No jeho krátke, menej než dve sezóny trvajúce pôsobenie, takúto ambíciu iba naznačilo. Dramaturgia v snahe pokračovat’ v línii uvádzania pôvodných hier zaradila do plánu premiér dve nové diela Petra Karvaša, autorskú reflexiu o období kultu osobnosti z pätdesiatych rokov Jazva (1964) a spoločenskú alegóriu Vel’ká parochňa (1965), a Lišky, dobrú noc Igora Rusnáka (1964). Slovenské hry si nenašli svojho režiséra, každú inscenoval iný. Azda len Bobulov náhly odchod zapríčinil, že na svoju inscenáciu Jazvy nenadviazal Vel'kou parochňou, ktorú medzi Verdiho Silou osudu a Suchoňovou Krútňavou inscenoval operný režisér (!) Kornel Hájek. Ani jedna inscenácia neznamenala výraznejší čin, pričom Katušova réžia Rusnákovej hry trpela značnou simplifikáciou príbehu a prvoplánovostou. V tomto období sa tiež znásobujú Chmelkove nepresvedčivé umelecké výsledky, dôkazom je aj jeho málo ambiciózna dramaturgia: už trochu anachronický Jánošík (1965) Márie Rázusovej-Martákovej a Knieža Rastic (1963) Lubomíra Smrčka.

Košická dramaturgia následne na dlhšie obdobie rezignovala na uvádzanie pôvodných hier. Snažila sa však zachytit’ trend novej americkej a západoeurópskej drámy, ked' súbor naštudoval Zostup Orfea Tennesseeho Williamsa (1964) a Návštevu starej dámy Friedricha Dürrenmatta (1965). Druhá menovaná patrila k najúspešnejším inscenáciám daného obdobia, ktorou Katuša nadviazal na rovnako úspešnú Andorru. Z vel'kých plátien hodno spomenút' Shakespearovho Romea a Júliu (1964). No napriek čiastkovým úspechom, inscenačný Bobulov prístup ukotvený v tradičnej réžii a pár vydarených Katušových nedokázali vytvoritł tak prepotrebný tvorivý dialóg.

Dve sezóny nasledujúce po odchode Milana Bobulu sa niesli v znamení pokračujúceho hladania nielen dramaturgickej koncepcie, ale predovšetkým vhodnej umeleckej (režisérskej) osobnosti, ktorá by ju na pozícii umeleckého šéfa súboru dokázala naplnit'. Zborovjan prebral vedenie súboru, ale len ako zastupujúci umelecký šéf. Ani

\footnotetext{
${ }^{39}$-mm-. [M. Mayerová]. O dnešnom sovietskom divadle. Alexej Nikolajevič Arbuzov : Taňa [Bulletin k inscenácii]. Košice : Štátne divadlo, 1957, s. 9.

${ }^{40}$ Tamže, s. 8.
} 


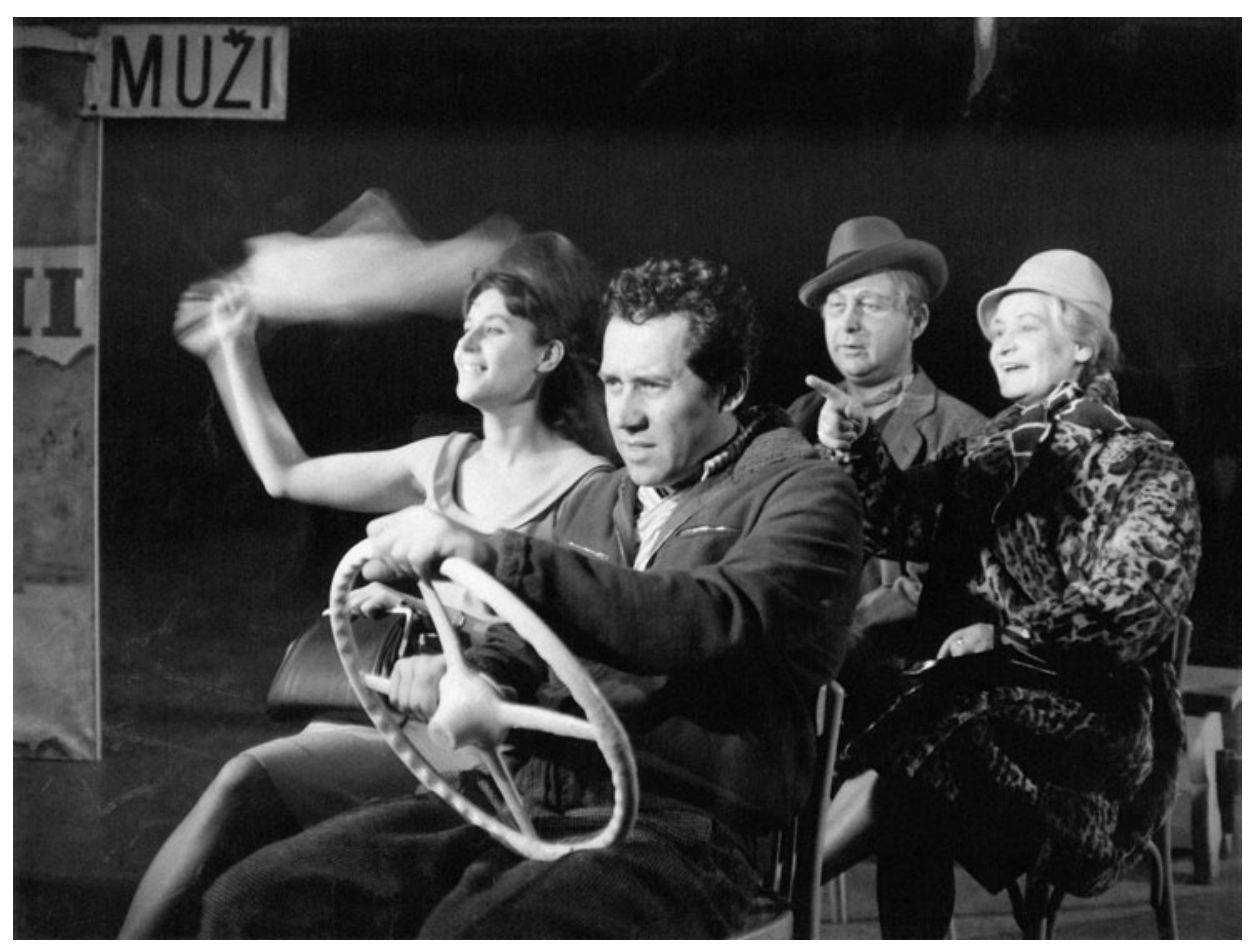

Friedrich Dürrenmatt: Návšteva starej dámy. Štátne divadlo Košice, premiéra 27. 3. 1965. Réžia Oto Katuša. Darina Poldaufová (Illova dcéra), Marián Kleis (Illov syn), Ján Bzdúch (Ill), Anna Grissová (Illova žena). Foto archív Štátneho divadla Košice. Snímka Mária Litavská.

nástup novej dramaturgickej posily, lektorky Gizely Mihálikovej (1965), neznamenal obrat k zmysluplnejšej dramaturgii. V sezóne 20. výročia vzniku divadla (1965/1966) má dramaturgia ambíciu prezentovat’ závažnejšie témy prostredníctvom rôznych autorských poetík (Lorenzaccio Alfreda Musseta, Tragédia človeka Imreho Madácha, sčasti aj Manon Lescaut Vítězslava Nezvala, oblúbeného básnika Júliusa Zborovjana). No v nasledujúcej sa už o to ani nepokúša, Dostojevského Zločin a trest osamotene vyčnieva z radu nenáročných, zväčša komediálnych titulov. Absencia ústrednej formotvornej osobnosti bola kompenzovaná pozývaním hostujúcich režisérov. No napriek ich skúsenosti (Tibor Rakovský - Tragédia človeka) a talentu (Karol Spišák Zločin a trest) s problematickými výsledkami. Pokračovala snaha zachytit’ nové prúdy v súdobej dramaturgii (Sławomir Mrożek: Tango, 1967; Tennessee Williams: Leto a dym, 1966), v celku však išlo o obdobie improvizácie. Ako konštatuje Ján Jaborník, bolo to „systémom ,mixáže', v ktorej náročnú, hodnotnú dramatiku vyvažovali a ,vyl'ahčovali' komerčné, ideove a umelecky nezáväzné tituly“41.

Ani nástup režiséra Vladimíra Petrušku na post umeleckého šéfa (1967) nemohol radikálnejšie zmenit tento stav. Problémy totiž tkveli príliš hlboko vo všetkých zložkách súboru. Dramaturgia sa síce nad’alej snažila reflektovat’ možnosti relatívne

${ }^{41}$ JABORNÍK, J. Minulost’ a prítomnost’ košickej činohry, s. 314. 
liberálnych šest’desiatych rokov, no nenašla partnera ani v režiséroch, ani v hereckej časti súboru. Z hodnotnejších hier súčasnej svetovej drámy možno spomenút O’Neillovu Túžbu pod brestami (1968), Dürrenmattových Fyzikov (1969), Shafferovu Čiernu komédiu (1969). Dramaturgia sa usilovala pokračovat’ v rodiacej sa košickej shakespearovskej tradícii (Antonius a Kleopatra,1967), doplnenej o d’alšiu alžbetínsku drámu, Volponeho (1968) Bena Jonsona v dramatizácii Stefana Zweiga. Zborovjan z časového hladiska a rozdielnosti režijných štýlov neadekvátne - začlenil premiéru hry Jeana Giraudouxa Bláznivá zo Chaillot (1968) do nadväzujúcej línie s hrami Jeana Anouilha a Marcela Acharda uvádzanými v Košiciach v štyridsiatych rokoch. Dlhoročný riaditel' Chmelko si na rozlúčku s divadlom zvolil Ibsenovu Pani z prímoria (1968).

Dramaturgia slovenských hier takisto nevykazovala známky premyslenejšej koncepcie. Rusnákovu a obe Karvašove hry zarad’ovali do repertoáru všetky relevantné divadlá na Slovensku. Nepodarilo sa naplnit ani zámer uviest’ nový dramatický text. Na sezónu 1966/1967 bola ohlasovaná Rusnákova nová hra Smrt’ si prišla po rytiera, no napokon ju nahradilo Mrożkovo Tango. Výsledkom bolo presunutie dramaturgickej pozornosti k overeným klasickým titulom, s rozporuplnými inscenačnými výsledkami: Katuša koncipoval Palárikovo Dobrodružstvo pri obžinkoch (1968) ako „národopisný večer hudby a tanca s činohernými vložkami z hry“42, Petruška Zvonov Tanec nad plačom (1968) ako „divadlo viac na úrovni frašky než veselohry“43.

Vrátit’ súčasnú tvorbu na košické javisko sa podarilo až tzv. zvieracou trilógiou Ivana Bukovčana (Pštrosí večierok, 1968; Kým kohút nezaspieva, 1969; Zažeň vlka, 1970). Košická činohra ju v takomto dramaturgickom celku uviedla ako jediná zo slovenských divadiel, avšak v nejednoznačných Petruškových réžiách. V období začínajúcej tzv. normalizácie viaceré divadlá - často viac z opatrnosti než pod vplyvom vonkajších „konsolidácií“ - neuviedli niekol'ko plánovaných hier. Tak sa do sezóny 1970/1971 nedostala Zborovjanova hra na motívy Záborského Faustiády, ohlasovaná pod názvom Doktor Faust v Kocúrkove.

Umelecké vedenie divadla si, aj na základe nekompromisných kritík, uvedomovalo zlú situáciu, a to najmä v režijnej zložke, so silným dopadom na herecký súbor. Zorganizovalo dve interné prehliadky. Kým prvá, ktorú inicioval poverený šéf Zborovjan (1966) problémy odhalila, druhá (1969) konštatovala ich prehĺbenie: „(...) úsilie o nové moderné divadlo sa nerealizovalo cestou vnútorného, organického a vývinového približovania $\mathrm{k}$ jeho vnútornej podstate, ale bolo prázdnou, módnou kampaňovitostou. “44 Absentoval vzájomný tvorivý dialóg režisérov, no predovšetkým dialóg dramaturgicko-režijný. Bobula trend načrtol, avšak v málo priebojnej, opatrnejšej podobe. Katuša sa netajil snahou odíst' do Bratislavy. Jeho réžie mali kvalitatívne zostupnú tendenciu, niektoré osamotene zažiarili, ako celok však neoslnili. Petruška tak prišiel do obdobia umeleckého aj l'udského rozkladu súboru. Na konci decénia opät režíruje aj herec Jozef Hodorovský a krízový stav dokladá prechod d’alšieho herca, Jána Ondrejku, do režisérskeho stavu. Z ich prác ani jedna nedokázala mat’ formujúci potenciál. Osamotený Petruška pozval do Košíc hostujúcich režisérov, ale ani Ivan Lichard (Jan Drda: Hriešna dedina alebo zabudnutý čert,

\footnotetext{
${ }^{42}$ GIM. [G. Mačugová]. Bez dialógu niet tvorby. In Práca, 1968, roč. 23, č. 102, s. 5, 12. 4. 1968.

${ }^{43}$ ČAVOJSKÝ, L. Ani do tanca, ani na počúvanie. In Pravda, 1968, roč. 49, č. 298, s. 2, 31. 10.1968.

${ }^{44}$ JABORNÍK, J. Minulost’ a prítomnost’ košickej činohry, s. 316.
} 


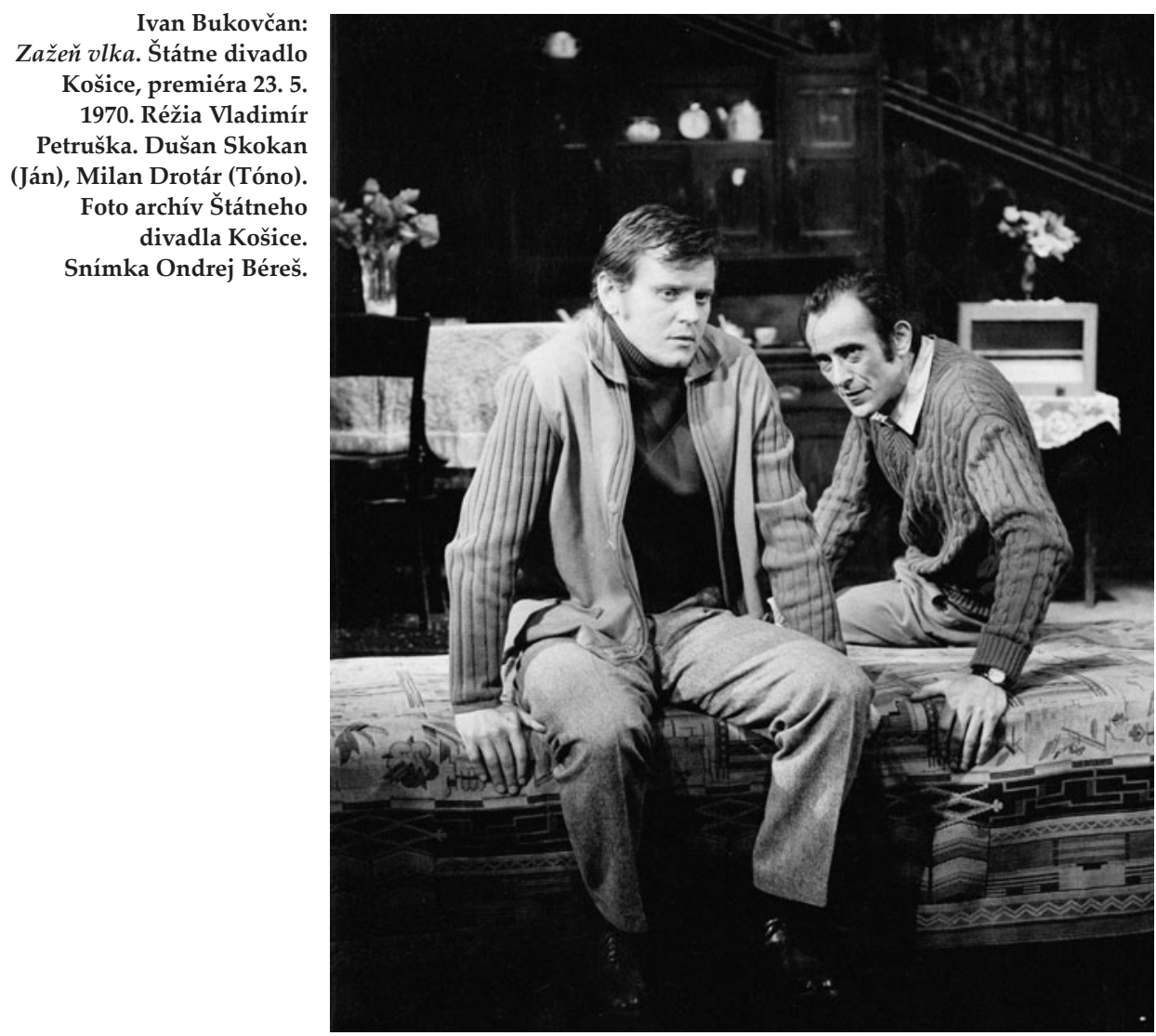

1969), ani Ivan Petrovický (Peter Shaffer: Čierna komédia, 1969) nedokázali prelomit’ železnú tradíciu košického herectva. O ňu sa, paradoxne, do istej miery oprel a v súčasnejšom a poetickejšom duchu ju exploatoval sovietsky režisér Anatolij Alexandrovič Rotenštejn. Jeho inscenácia hry Maxima Gorkého Meštiaci (1970) znamenala pre staršiu hereckú generáciu dramaturgickú istotu a jasný oporný bod v psychologicko-realistickej metóde. Inscenácia bola väčšinou kritiky dokonca označovaná ako rehabilitácia košickej činohry.

V tomto prostredí a v takýchto podmienkach nebolo jednoduché nastavit’ zmysluplný dramaturgický plán, ktorý by reflektoval stav súboru. Zborovjan deklaroval košickú dramaturgiu ako vyváženú, išlo však o výrazné lavírovanie medzi izolovanými umeleckými snaženiami režisérov a ambíciami hereckých protagonistov, s prílišnou snahou zaplátat’ košické činoherné diery dramaturgickými trendmi doby. Ambíciami, ktoré v čase vrcholiacej krízy súboru Petruška ironicky pomenoval ako snahu o „,tzv. odborárske divadlo (...), v ktorom sa uplatní každý jeden herec ${ }^{\prime 45}$.

${ }^{45}$ KRAUS, Tomáš. Kto to v Košiciach dokáže? In Sloboda, 1969, roč. 24, č. 5, s. 8, 31. 1. 1969. 


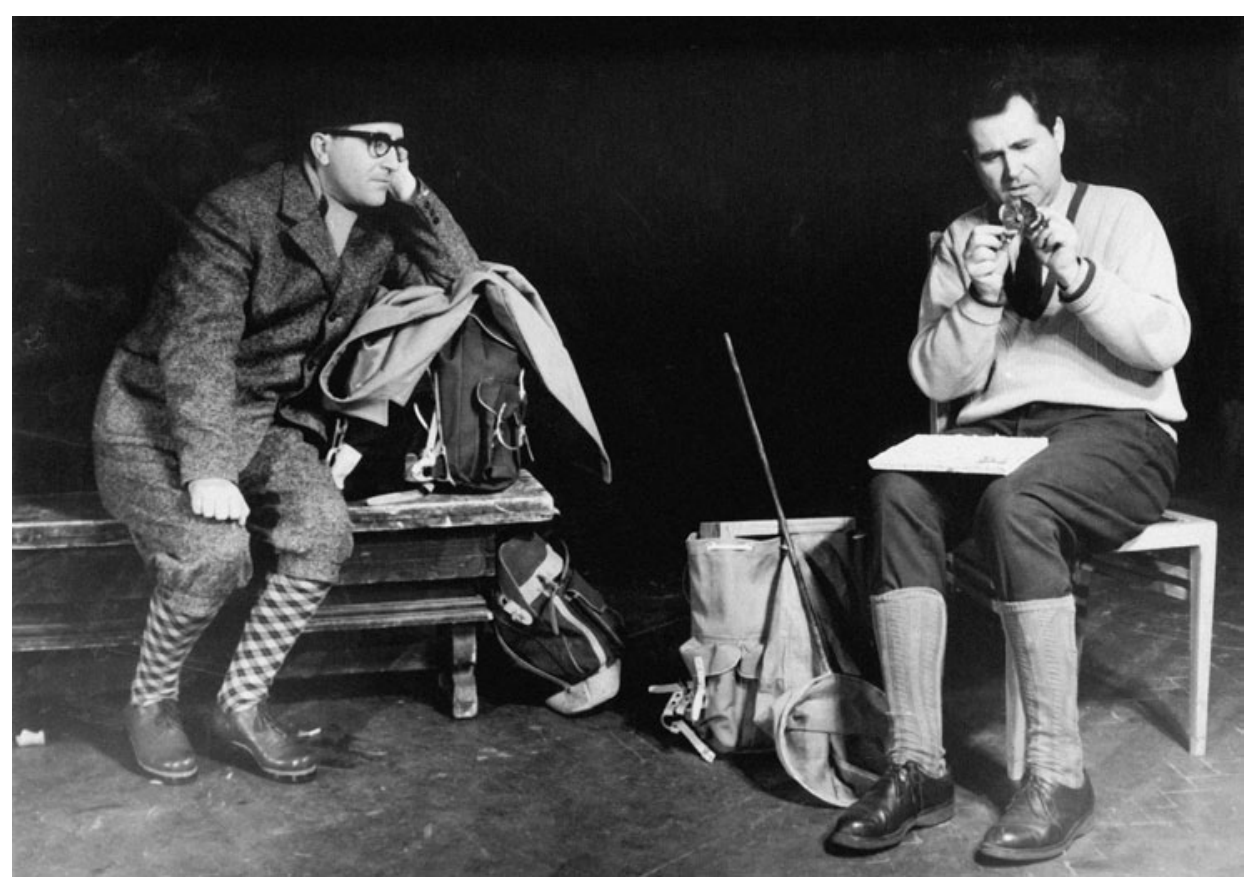

Ludovít Filan: Motýle. Štátne divadlo Košice, premiéra 3.2.1962. Réžia Jozef Palka. Jozef Hodorovský (Inž. Milan Tomeš), Ján Bzdúch (Vojto Kramár). Foto archív Štátneho divadla Košice. Snímka Mária Vajdová.

Ani nástup d’alšieho dramaturga, Ladislava Obucha (1968), na stave nič nezmenil, hoci mal potenciál revitalizovat’ overenú spoluprácu dvoch interných dramaturgov, akú košická činohra zažila na prelome pätdesiatych a šest’desiatych rokov. Tak ako $\mathrm{v}$ prípade Mayerovej, aj Obuch inklinoval „k hrám híbavej filozofickej a psychoanalytickej zložitosti, k vecnejšej rozumovej argumentácii“, kým Zborovjan „,k lyrike, romantizmu a krehkejšej citovej hravosti“ ${ }^{46}$ Dramaturgia deklarovala snahu sústredit” sa viac na moderné prúdy v svetovej dramatike (so zameraním na absurdnú drámu a antidrámu) a divadle. No s jediným interným režisérom (Petruška) a rezervovaným vztahom mimokošických režisérov ku košickej činohre sa ambiciózny plán nenaplnil. V sezóne 1968/1969 napokon uviedli iba pät celovečerných premiér. Obuchov náhly odchod na jej konci len potvrdzoval názory slovenskej divadelnej obce o zlej atmosfére v košickom divadle a o dedičstve „principálsko-hereckého divadla borodáčovského a chmelkovského" ${ }^{47}$.

${ }^{46}$ Takto svoje štýlové a poetické preferencie charakterizovali samotní dramaturgovia. -čok. [K. Jančošek]. Problémy narastajú... In Film a divadlo, 1968, roč. 12, č. 25, s. 3, 5. 12. 1968.

${ }^{47}$ DEDINSKÝ, M. M. Dedičstvo divadla principálsko-hereckého. In Slovenské divadlo, 1970, roč. 18, č. 1, s. 35 . 


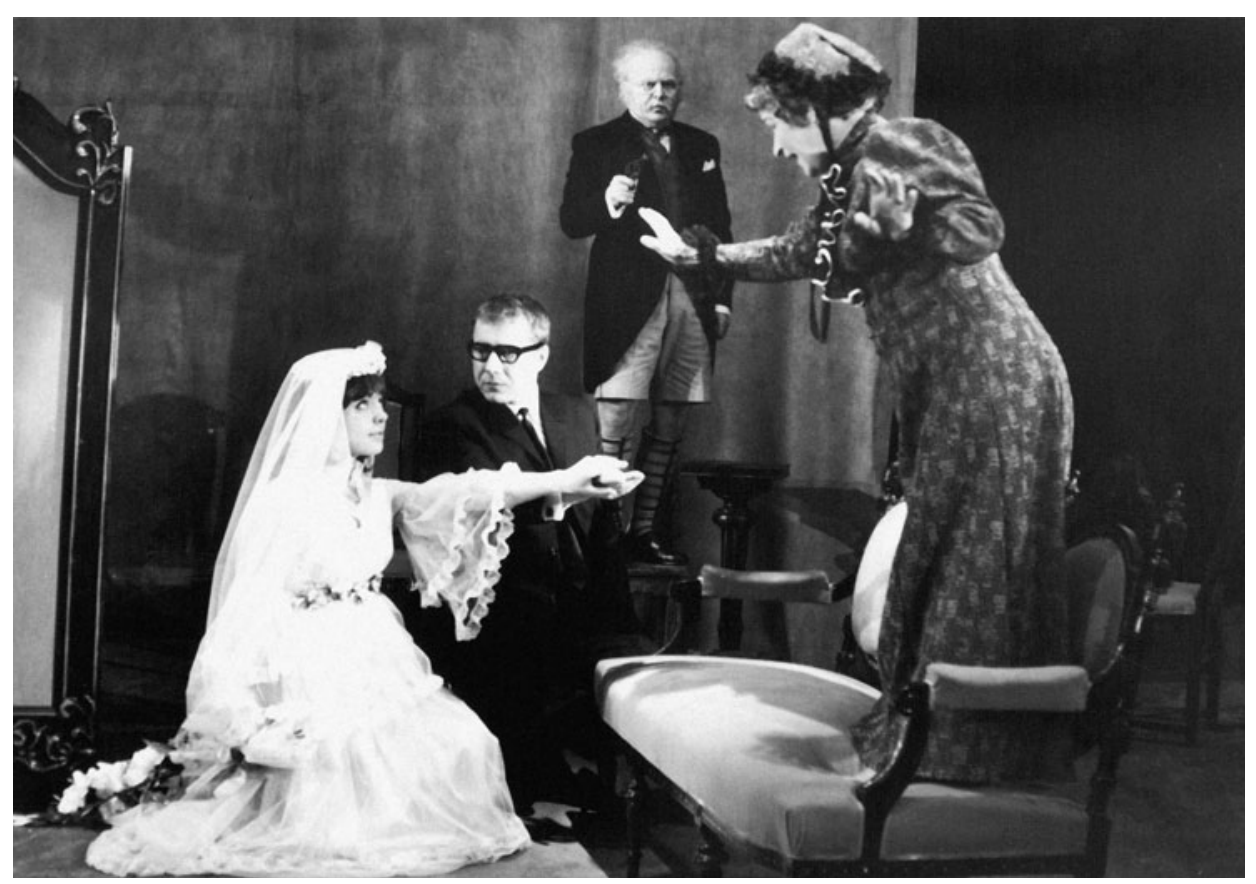

Slawomir Mrożek: Tango. Štátne divadlo Košice, premiéra 15. 4. 1967. Réžia Oto Katuša. Jela Bučková (Ala), Peter Gažo (Artur), Peter Macko (Eugen), Anna Grissová (Eugénia). Foto archív Štátneho divadla Košice. Snímka Mária Litavská.

\section{Záver}

V dejinách košickej dramaturgie do roku 1970 existuje niekol'ko línií, ktoré - v rôznych motiváciách a inscenačných výsledkoch - majú jedného spoločného menovatel'a. Je to snaha o prvé slovenské uvedenie dramatických autorov na profesionálnom javisku, respektíve ich jednotlivých hier. Z francúzskych možno spomenút Jeana Giraudouxa, Jeana Anouilha, zo španielskych Alejandra Casonu, zo švajčiarskych Maxa Frischa, z talianskych Carla Gozziho, z ruských Michaila Jurieviča Lermontova, z mad’arských Imreho Madácha, zo slovenských Jána Chalupku, Juraja Severa, z dramatizovanej prózy Martina Kukučína. Z tvorby súčasných dramatikov mali slovenskú premiéru napríklad diela Petra Karvaša Hra o básnikovi a Srdce plné radosti, Veža a Kde bolo, tam bolo Júliusa Barča-Ivana a Jej proý ples Ivana Stodolu, A bolo svetlo a Motýle L'udovíta Filana, Bohovia Amsterdamu Juraja Váha, zo svetovej dramatiky napríklad Othello (v češtine) a Antonius a Kleopatra (Shakespeare), Najlepší sudca (Lope de Vega), Sluha dvoch pánov, Starý frfloš, Rozmarná žena (Goldoni), Lekárom proti svojej wôli (Molière), Don Carlos (Schiller), Lorenzaccio (Musset), Tragédia človeka (Madách), Maškaráda (Lermontov), Smrt' obchodného cestujúceho (Miller), Tango (Mrożek).

Dramaturgia košických profesionálnych činohier, v medzivojnovom období aj po roku 1945, bola limitovaná ne/existenciou inscenačnej tradície a hereckými možnost’ami jednotlivých súborov. Forma a charakter prvého aj druhého VND neumožňo- 
vali vnímat’ dramaturgickú činnost’ v jej ideovo-estetických a tvorivo-formatívnych poslaniach. Jej nositel'om bol režisér, respektíve riaditel', ucelenejšie dramaturgické okruhy sa dajú vysledovat' len minimálne. Aj po vzniku stálej profesionálnej scény (1945) bol dramaturg zbavený tvorivých a konštruktívnych možností dialogizovat’ svoj vztah s režisérom, v oklieštenej podobe koncentroval svoju pozornost' do textovej a literárno-historickej predprípravy ako servisnej činnosti. Ani opačný, independentný prístup nepriniesol požadované výsledky. Dramaturg sa často opieral o príležitost’ realizovat’ v dramaturgii svoje žánrové a prekladatel'ské priority. Iba koncepčná, ideovo-estetická a tvorivo podnecujúca dramaturgická práca, v úzkom dialógu s režisérom/mi, mala potenciál aktivizovat’ činoherný súbor, odkrývat jeho herecké predpoklady, zbavovat’ ho nánosov realistického herectva v jeho borodáčovsky uzavretej podobe. Najucelenejšie úspechy dosahovala košická činohra práve v obdobiach medzirežisérskych a režisérsko-dramaturgických dialógov. Nádejne, ale príliš krátko sa o to pokúšal Chmelko v prvých rokoch nového divadla, v Palkovom a Katušovom období bol dialóg rozšírený o dramaturgický a medzidramaturgický diškurz.

V druhej polovici šest’desiatych rokov sa akýkolvvek dialóg vytratil. Bobula a Petruška nedokázali podnecovat dramaturgickú činnost', neatakovali postupnú zotrvačnost' Katušových réžií, ktorá vyústila do jeho rezignácie na zmysluplnejšiu prácu so súborom a odchodu z Košíc. Chmelkove režijné prefabrikáty sa obmedzovali už len na príležitostnú dramaturgiu (výročia). Zborovjan dokázal formulovat', ale nie formovat’ jednotiacu líniu činohernej dramaturgie ako výslednice súčasného dramaturgického myslenia: dlhodobej, umeleckej vízie s ohl’adom na vnútrosúborové možnosti a úroveň publika. Zostával v týchto snaženiach často a dlhodobo osamotený.

\section{THE METAMORPHOSES OF KOŠICE DRAMATURGY OF DRAMA THEATRE (1924 - 1970)}

\section{Peter HIMIČ}

The study outlines the development of the dramaturgy of drama theatre in the Slovak professional theatre in Košice, from the founding of the East Slovak National Theatre in 1924, down to the beginning of the so-called normalisation period. It names basic dramaturgical strands and developmental trends. The history of Košice professional theatre has several problematic stages. To a limited extent, there were compact dramaturgical time periods, however, they only sporadically evolved into a long-lasting art manifesto.The non-existence of a more intensive and ideologically and aesthetically founded dramaturgical vision with respect to the drama ensemble and directorial work is among the major reasons for the situation. Moreover, the situation was oftentimes complicated bythe dominance of theatre directors sometimes surpassing their artistic potential. A clash between the older and the younger generations coming on the scene seemed to have also played a key role, the latter being impacted by the post-war modern drama and theatre. 


\section{LITERATÚRA}

BOBOK, Jozef. Kalinčiakova „Reštavrácia“ na scéne Štátneho divadla v Košiciach (Poznámky k dramatizácii a k inscenácii). In Slovenské divadlo, 1956, roč. 4, č. 2, s. 148 - 159. ISSN 0037-699X.

ČAVOJSKÝ, Ladislav. Ani do tanca, ani na počúvanie. In Pravda, 1968, roč. 49, č. 298, s. 2, 31. 10. 1968.

-čok. [Karol Jančošek]. Problémy narastajú... In Film a divadlo, 1968, roč. 12, č. 25, s. 3, 5. 12.1968.

FERKO, Tibor. Skice o košickej činohre v jubilejnom formáte. In Slovenské divadlo, 2016, roč. 64, č. 1, s. 67 - 81. ISSN 0037-699X.

FOJTÍKOVÁ FEHÉROVÁ, Dária. Ferdinand Hoffmann - rozhl’adený dramaturg. In Ferdinand Hoffmann. Kritik, dramaturg, režisér... (Eds. Vladimír Štefko, Dária Fojtíková Fehérová, Martin Timko.) Bratislava : Divadelný ústav, 2015, s. 200 - 213. ISBN 978-80-89369-84-3.

GIM. [Gizela Mačugová]. Bez dialógu niet tvorby. In Práca, 1968, roč. 23, č. 102, s. 5, 12. 4.1968.

GOJDA, Mikuláš Štefan. Dvadsat rokov činohry ŠD. In ZBOROVJAN, J. a kolektív. 20 rokov Štátneho divadla v Košiciach. Košice : Východoslovenské vydavatel'stvo, 1965, s. 29 - 43.

HIMIČ, Peter. Divadlo na východnom Slovensku I. : Od počiatkov do roku 1945. Banská Bystrica : Fakulta dramatických umení, Akadémia umení v Banskej Bystrici, 2020. 132 s. ISBN 97880-8206-034-1.

HIMIČ, Peter. Janko Borodáč - Andrej Chmelko. Dve cesty - jeden smer. In Slovenské divadlo, 2019, roč. 67, č. 1, s. 40 - 57. DOI: 10.2478/sd-2019-0003. ISSN 0037-699X.

CHMELKO, Andrej. Spoza opony. Vydal Andrej Chmelko, 1996. 79 s.

CHMELKO, Andrej. S Barčom do tretej sezóny. In Július Barč Ivan : Veža [Bulletin k inscenácii]. Košice : ND v Košiciach, 1947.

JABORNÍK, Ján - ČAHOJOVÁ, Božena. Peter Karvaš. In ŠTEFKO, Vladimír a kol. Dejiny slovenskej drámy 20. storočia. Bratislava : Divadelný ústav, 2011, s. 355 - 385. ISBN 978-80-8936936-2.

JABORNÍK, Ján. Minulost’ a prítomnost’ košickej činohry. In Slovenské divadlo, 1973, roč. 21, č. 3, s. 305 - 336. ISSN 0037-699X.

JABORNÍK, Ján. Tridsatpät rokov činohry. In 35 rokov Štátneho divadla v Košiciach. (Ed. Štefan Fejko.) Košice : Štátne divadlo, 1980, s. 4-14.

JABORNÍK, Ján. Košická sezóna Magdy Husákovej-Lokvencovej (1955 - 1956). In LINDOVSKÁ, Nadežda a kolektív autorov. Magda Husáková-Lokvencová : prvá dáma slovenskej divadelnej réžie. Bratislava : Divadelný ústav, Vysoká škola múzických umení, Divadelná fakulta, 2008, s. 131 - 176. ISBN 978-80-88987-79-6.

Jša. [Jan Škoda] Čin. K premiére „Tragédie človeka“. In Za oponou, 1925, roč. 2, č. 16, s. 13.

KRAUS, Tomáš. Kto to v Košiciach dokáže? In Sloboda, 1969, roč. 24, č. 5, s. 8, 31. 1. 1969.

lk. Divadlo na východnom Slovensku a Podkarpatskej Rusi. In Za oponou, 1924, roč. 1, č. 4, s. 3.

List J. Borodáča Okresnému ústavu národného zdravia v Košiciach z 3. 2. 1953. Uložené v Štátnom archíve v Košiciach, Fond Štátne divadlo v Košiciach (1900) 1945-1995, osobný spis J. Borodáča, inv. č. 394.

List J. Borodáča J. Zborovjanovi z 24. 11. 1949. Uložené v Literárnom archíve Slovenskej národnej knižnice v Martine. Fond Julo Zborovjan, ev. č. 2828.

List Dr. M. H. Lokvencovej riaditel'ovi ŠD v Košiciach zo dňa 27. 1. 1956. Uložené v Štátnom archíve v Košiciach, Fond Štátne divadlo v Košiciach (1900) 1945-1995, osobný spis M. Husákovej-Lokvencovej, inv. č. 394.

MIŠOVIC, Karol. Náčrt k problematike režijnej a dramaturgickej tvorby Janka Borodáča počas pôsobenia v Košiciach. In Slovenské divadlo, 2019, roč. 67, č. 1, s. 23 - 39. DOI: 10.2478/sd2019-0002. ISSN 0037-699X.

MITTELMANN-DEDINSKÝ, Móric. Dedičstvo divadla principálsko-hereckého. In Slovenské divadlo, 1970, roč. 18, č. 1, s. 25 - 35. ISSN 0037-699X. 
Nikolaj Vasilievič Gogol' : Revízor [Bulletin k inscenácii]. Košice : Národné divadlo v Košiciach, 1952. -mm-. [Margita Mayerová]. Bohovia Amsterdamu - história či prítomnost? Juraj Váh : Bohovia Amsterdamu [Bulletin k inscenácii]. Košice : Štátne divadlo, 1959.

-mm-. [Margita Mayerová]. O dnešnom sovietskom divadle. Alexej Nikolajevič Arbuzov : Taňa [Bulletin k inscenácii]. Košice : Štátne divadlo, 1957.

PAŠUTHOVÁ, Zdenka. Činoherné divadlo v rokoch 1920 - 1932. In Dejiny slovenského divadla I. Bratislava : Divadelný ústav, 2018, s. 133 - 189. ISBN 978-80-8190-039-6.

POLÁK, Milan. Premiéry Východoslovenského národného divadla v Košiciach 1924 - 1930 a 1937 1938. Bratislava : Národné divadelné centrum, 1995. 112 s. ISBN 80-85455-18-8.

RAMPÁK, Zoltán. Z minulosti VND v Košiciach : 1920 - 1938. In Národné divadlo v Košiciach : Jubilejné číslo programu ND v Košiciach. (Zredigoval Julo Zborovjan). Košice : ND v Košiciach, 1955, s. $18-25$.

ŠKODA, Jan. Niekol'ko čísiel o Východoslovenskom Národnom divadle v Košiciach. In Slovenský východ, 1925, roč. 7, č. 143, s. 5, 26. 6. 1925.

ŠTEFKO, Vladimír. Od realizmu k moderne 1890 - 1938. In ŠTEFKO, Vladimír a kol. Dejiny slovenskej drámy 20. storočia. Bratislava : Divadelný ústav, 2011, s. 15 - 44. ISBN 978-80-8936936-2.

ZBOROVJAN, Julo. Informatívne o činohre. In Národné divadlo v Košiciach : Jubilejné čislo progra$m u$ ND v Košiciach. (Zredigoval Julo Zborovjan). Košice : ND v Košiciach, 1955, s. 40 - 56.

Peter Himič

Fakulta dramatických umení

Akadémia umení v Banskej Bystrici

J. Kollára 22

97401 Banská Bystrica

e-mail: himicpeter@gmail.com 